OPEN ACCESS

Edited by:

Maria Cristina D'Adamo,

Charité - Universitätsmedizin Berlin,

Germany

Reviewed by:

Imre Vida,

Charité - Universitätsmedizin Berlin,

Germany

Giuseppe Di Giovanni

University of Malta, Malta

*Correspondence:

Jakob Wolfart,

Oscar Langendorff Institute of

Physiology, University of Rostock

Gertrudenstr. 9

18057 Rostock, Germany

jakob.wolfart@uni-rostock.de

Specialty section:

This article was submitted to

Membrane Physiology and Membrane

Biophysics,

a section of the journal

Frontiers in Physiology

Received: 04 March 2015

Accepted: 19 May 2015

Published: 15 June 2015

Citation:

Wolfart J and Laker D (2015)

Homeostasis or channelopathy? Acquired cell type-specific ion channel changes in temporal lobe epilepsy and their antiepileptic potential.

Front. Physiol. 6:168.

doi: 10.3389/fphys.2015.00168

\section{Homeostasis or channelopathy? Acquired cell type-specific ion channel changes in temporal lobe epilepsy and their antiepileptic potential}

\author{
Jakob Wolfart* and Debora Laker \\ Oscar Langendorff Institute of Physiology, University of Rostock, Rostock, Germany
}

Neurons continuously adapt the expression and functionality of their ion channels. For example, exposed to chronic excitotoxicity, neurons homeostatically downscale their intrinsic excitability. In contrast, the "acquired channelopathy" hypothesis suggests that proepileptic channel characteristics develop during epilepsy. We review cell type-specific channel alterations under different epileptic conditions and discuss the potential of channels that undergo homeostatic adaptations, as targets for antiepileptic drugs (AEDs). Most of the relevant studies have been performed on temporal lobe epilepsy (TLE), a widespread AED-refractory, focal epilepsy. The TLE patients, who undergo epilepsy surgery, frequently display hippocampal sclerosis (HS), which is associated with degeneration of cornu ammonis subfield 1 pyramidal cells (CA1 PCs). Although the resected human tissue offers insights, controlled data largely stem from animal models simulating different aspects of TLE and other epilepsies. Most of the cell type-specific information is available for CA1 PCs and dentate gyrus granule cells (DG GCs). Between these two cell types, a dichotomy can be observed: while DG GCs acquire properties decreasing the intrinsic excitability (in TLE models and patients with HS), CA1 PCs develop channel characteristics increasing intrinsic excitability (in TLE models without HS only). However, thorough examination of data on these and other cell types reveals the coexistence of protective and permissive intrinsic plasticity within neurons. These mechanisms appear differentially regulated, depending on the cell type and seizure condition. Interestingly, the same channel molecules that are upregulated in DG GCs during HS-related TLE, appear as promising targets for future AEDs and gene therapies. Hence, GCs provide an example of homeostatic ion channel adaptation which can serve as a primer when designing novel anti-epileptic strategies.

Keywords: hippocampus, homeostasis, kainic acid, pilocarpine, channelacoids 


\section{Introduction}

The relationship between epileptic seizures and ion channels is typically focused on the proepileptic (meaning seizuresupporting) nature of ion channel abnormalities. This perspective, embodied in the terms "channelopathy" and "channelepsy" (Hoffman, 1995; Ptacek, 1997; George, 2004; Kullmann and Waxman, 2010; D'adamo et al., 2013), is fueled by the increasing number of ion channel mutations discovered in epilepsy patients (Biervert et al., 1998; Charlier et al., 1998; Singh et al., 1998, 2008; Zuberi et al., 1999; Heilstedt et al., 2001; Chioza et al., 2002; Schulte et al., 2006; Cavalleri et al., 2007; Tomlinson et al., 2010; Lachance-Touchette et al., 2011; Weckhuysen et al., 2013), and the seizure phenotypes of corresponding engineered channel mutants (Signorini et al., 1997; Schroeder et al., 1998; Smart et al., 1998; Spigelman et al., 2002; Ludwig et al., 2003; Peters et al., 2005; Huang et al., 2009; Ishii et al., 2009; Riazanski et al., 2011; Hedrich et al., 2014). In contrast to genetic channelopathies, an "acquired channelopathy" is declared when ion channel abnormalities develop independently of the genetic background (Waxman, 2001; Bernard et al., 2004; Poolos and Johnston, 2012). Thus, the prevailing view of progressive acquisition of proepileptic channel properties during epilepsy is conceptually similar to the old "seizures beget seizures" hypothesis (Gower, 1881; Hauser and Lee, 2002; Sills, 2007; Ben-Ari, 2008).

For those studying homeostasis, the acquired channelopathy scenario may appear puzzling; how is it possible that neurons exposed to an environment already hyperexcitable, further enhance their excitability in a potentially self-destructive manner? Usually, biological cells are well equipped to counteract detrimental excitation and especially neurons respond to extrinsic hyperexcitation with intrinsic hypoexcitability on all time scales (Davis and Bezprozvanny, 2001; Turrigiano and Nelson, 2004; Marder and Goaillard, 2006; Meier et al., 2015). Are these mechanisms of protective homeostasis disabled in epilepsy? And if so, is it the rule or rather the exception? It is important to answer these questions, because it will help to understand the mechanisms of seizures and antiepileptic drugs (AEDs). The prevailing AED strategy is to inhibit excitatory channels such as sodium (Na) and calcium (Ca) channels (Löscher et al., 2013). A more recent approach is to support a specific potassium (K) channel (further discussion below) (Tatulian et al., 2001; Faulkner and Burke, 2013). Generally, AED strategies imply relatively fixed ion channel repertoires, but channels are dynamically adjusted all the time and these changes are not well understood in particular with respect to epilepsy.

Most of the discussion on channel-related AED mechanisms of action takes place without mentioning cell types even though AED channel targets can have behaviorally opposed effects depending on which cell types are affected (Prakriya and Mennerick, 2000; He et al., 2002). Hence, to discuss antiepileptic strategies in a meaningful manner, the first step is to obtain an overview on available information about channel molecule alterations, cell types, and epilepsy model methods. The present review focuses on temporal lobe epilepsy (TLE), because the majority of the available data concern this most common form of partial epilepsies, which in turn account for $60 \%$ of all adult epilepsy cases (Tellez-Zenteno and Hernandez-Ronquillo, 2012). Some of the discussed channel mechanisms might also be relevant for other epilepsies as many TLE animal models display generalized seizures. Studies on the principal neurons of the hippocampal formation, especially cornu ammonis 1 (CA1) and dentate gyrus (DG), outnumber studies on other areas by far. This fact is mirrored in our list of acquired ion channel alterations (Table 1). Other cell types are expected to gain importance in the future and are also discussed in respective sections. We especially highlight channels with net inhibitory effects and relate these to existing or promising AED mechanisms of action (Table 2), asking whether certain cell types can signpost effective molecule target combinations for future AED and antiepileptic gene therapies.

\section{Temporal Lobe Epilepsy}

TLE seizures start in the temporal lobe and impair the consciousness, among other symptoms (Blumenfeld and Meador, 2014). TLE is often refractory to AEDs; therefore, anterior temporal lobe resection is a standard treatment (De Tisi et al., 2011). In its most common form, TLE affects the medial temporal/limbic network with involvement of the entorhinal cortex, the amygdala, and the hippocampus with the DG and the CA regions 1-3 (hippocampus sensu strictu) (Spencer, 2002). The neuropathological correlate of TLE is hippocampal sclerosis (HS) (Margerison and Corsellis, 1966; Curia et al., 2014) and quite often is HS interpreted to be the cause of TLE (Blümcke et al., 2012). However, as human TLE is heterogeneous, it appears difficult to find even simple correlations between the severity of HS and epileptic seizures, let alone the certainty that HS causes TLE or indeed vice versa (King et al., 1997; Jefferys, 1999; Blümcke et al., 2002; Mathern et al., 2002; Sutula et al., 2003; De Lanerolle and Lee, 2005; Briellmann et al., 2007; Mueller et al., 2007). A widespread criterion for HS diagnosis is loss of more than half of the CA1 PCs (Wyler et al., 1992). Other structural changes associated to HS, are sprouting of the mossy fiber axons of DG granule cells (GCs) (Sutula et al., 1989), changed GC morphology (Isokawa and Levesque, 1991), and GC dispersion (GCD) (Houser, 1990). Severe HS is correlated with severe GCD (Thom et al., 2002), although this relationship is not always strict (Blümcke et al., 2013). Occasionally, studies counting cells per area confuse GCD with degeneration of GCs. However, GCs are only lost in extreme HS (Wyler grade IV), i.e., when most of the CA1 PCs have already degenerated (Wyler et al., 1992). More than $90 \%$ of the hippocampi resected during epilepsy surgery exhibit HS (Blümcke et al., 2012) but it should be kept in mind that the decision on surgery itself depends on HS because the success rates of epilepsy surgery are higher with diagnosis of a lesion (Jobst and Cascino, 2015). Unbiased postmortem studies reveal HS in about half of TLE patients (Thom et al., 2010).

Epilepsy surgery offers direct experimental access to living human hippocampal tissue but lack of proper control tissue makes animal models indispensable. Different approaches were used to simulate a chronic epileptic state with anatomical changes resembling TLE. Since human TLE is heterogeneous and has 
unknown causes, animal models can only reproduce partial aspects of the disease (Coulter et al., 2002; Morimoto et al., 2004). One hypothesis for TLE is an initial precipitating injury (Mathern et al., 2002). Therefore, most animal models generate a chronic epileptic state via one status epilepticus (SE). Widespread is SE induction via i.p. (systemic) injection of kainate (sKA) (Nadler et al., 1978; Ben-Ari, 1985) or pilocarpine (sPilo) (Turski et al., 1983, 1989). The sKA and sPilo models produce generalized seizures and bilateral brain damage, the extent of which depends on the SE-termination protocol (Schwob et al., 1980; Turski et al., 1983). Often, no HS or only mild forms of it (noHS) occur in sKA and sPilo models (Okazaki et al., 1999; Scharfman et al., 2000; Dietrich et al., 2005; Curia et al., 2014). In contrast, development of HS and GCD, as well as focal spontaneous TLE seizures, can be induced by intracranial (intrahippocampal) kainate injection (iKA) (Suzuki et al., 1995; Fritschy, 2004). Another TLE model, which reproduces HS and chronic (bilateral) seizures, is perforant path stimulation-induced non-convulsive- (Kienzler et al., 2009) or convulsive SE (Bumanglag and Sloviter, 2008). In addition, there are different forms of electrical stimulation ("kindling") of amygdala or hippocampus (aKindl, hKindl) which mostly evoke seizures only during the stimulation (i.e., no chronic epilepsy), (Goddard et al., 1969; Mcnamara, 1984; Morimoto et al., 2004).

\section{Dentate Gyrus}

The DG is often viewed as a strategic "gate keeper" of the hippocampus and failure in its filter function was hypothesized to be a potential cause for TLE seizures (Heinemann et al., 1992; Lothman et al., 1992; Hsu, 2007; Krook-Magnuson et al., 2015). An alternative hypothesis is that the DG does not actively contribute to hippocampal seizures (Sloviter, 1994; Liu et al., 2000; Harvey and Sloviter, 2005). The following changes were considered responsible for a proepileptic role of the DG (De Lanerolle et al., 1992; Mody et al., 1992b): (i) mossy fiber sprouting (Tauck and Nadler, 1985; Sutula et al., 1989), (ii) loss of specific interneurons (Sloviter, 1987; Magloczky and Freund, 2005), and (iii) intrinsic hyperexcitability of the principal DG neurons, the GCs (Magloczky et al., 1997; Beck et al., 1998; Dietrich et al., 1999; Coulter, 2000; De Lanerolle et al., 2003; Selke et al., 2006; Mehranfard et al., 2014a). In contrast to the last point, many studies concluded that TLE does not change DG GCs intrinsically (Mody et al., 1992a; Beck et al., 1996; Isokawa, 1996; Molnar and Nadler, 1999; Okazaki et al., 1999; Scharfman et al., 2003; Dietrich et al., 2005; Beck and Yaari, 2008). Contrary to both prior hypotheses, we found a decrease of the intrinsic excitability of GCs which was due to a reduction in input resistance $\left(R_{\text {in }}\right)$; it occurred in samples of TLE patients with HS vs. mild/no HS as well as in iKA vs. control mice (Stegen et al., 2009, 2012; Young et al., 2009; Kirchheim et al., 2013). A reasonable question is: why are there so many disparate results on the same cell type (Vida, 2009)? With rare exceptions (Isokawa and Mello, 1991; Mehranfard et al., 2014b), most studies reporting unchanged GCs were those employing TLE models without HS. In TLE patients and the iKA TLE model, the $\mathrm{R}_{\text {in }}$ of DG GCs correlates with the degree of HS (Stegen et al., 2009, 2012; Young et al., 2009). Although it cannot be ruled out that some of the studies missed $\mathrm{R}_{\text {in }}$ differences due to methodological procedures, such as applying minimum $\mathrm{R}_{\mathrm{in}}$ as cell selection criterion, low seal resistance sharp electrodes, or by dissociating GC somata from their dendritic conductances (Mehranfard et al., 2014b), the conservative conclusion currently is: in TLE with HS, the ion channel expression of GCs is more drastically changed than in TLE without HS. It is important to note that GC channel adaptations only occur in the HS area, i.e., where GCD and neurodegeneration are clearly visible, but not outside of this HS focus. Ventral parts of the ipsilateral DG of iKA mice as well as the contralateral DG may even harbor hyperexcitable GCs (Le Duigou et al., 2008; Young et al., 2009; Häussler et al., 2012).

The molecular mechanism behind the reduced excitability of GCs is mainly transcriptional upregulation of $\mathrm{K}$ leak channels, i.e., channels that are open at resting membrane potential $\left(\mathrm{V}_{\text {rest }}\right)$ (Stegen et al., 2009, 2012; Young et al., 2009). Specifically, these are inwardly rectifying $\mathrm{K}\left(\mathrm{K}_{\mathrm{ir}}\right)$ channels of classic leak subtype $\mathrm{K}_{\mathrm{ir}} 2.1-4$ and two pore domain $\mathrm{K}$ leak channels of subtype $\mathrm{K}_{2 \mathrm{P}} 1.1$ and $\mathrm{K}_{2 \mathrm{P}} 6.1$. In addition, elevated tonic chloride $(\mathrm{Cl})$ leak conductances mediated by gamma amino butyric receptors type $\mathrm{A}\left(\mathrm{GABA}_{\mathrm{A}} \mathrm{Rs}\right)$ were detected in GCs of iKA mice (Young et al., 2009). Such tonic $\mathrm{GABA}_{\mathrm{A}}$ currents are likely mediated by extrasynaptic $\mathrm{GABA}_{\mathrm{A}}$ Rs composed of $\alpha 4-6$ plus $\beta$, and $\gamma 2$ or $\delta$ subunits (Peng et al., 2002; Zhang et al., 2007; Glykys et al., 2008) which could underlie epilepsy-related changes (Peng et al., 2004). In the adult stage, the $\mathrm{Cl}$ equilibrium potential $\left(\mathrm{E}_{\mathrm{Cl}}\right)$ of $\mathrm{GCs}$ is between $V_{\text {rest }}$ and action potential (AP) threshold, although $\mathrm{E}_{\mathrm{Cl}}$ can change during TLE (Palma et al., 2006; Huberfeld et al., 2007; Pathak et al., 2007; Khirug et al., 2010; Barmashenko et al., 2011). Therefore, the functional influence of TLE-related $\mathrm{GABA}_{\mathrm{A}}$ leak elevation is an enhancement of shunting inhibition. To explain the latter: if a large conductance $(1 / R)$ is added, its influence via Ohm's law $(\mathrm{U}=\mathrm{R} \times \mathrm{I})$ will minimize the voltage impact (U) of any further input currents (I). All conductances have this influence, but the counterintuitive effect of "inhibitory depolarization" occurs specifically when $E$ is between $V_{\text {rest }}$ and AP threshold, as with $\mathrm{E}_{\mathrm{Cl}}$ (Staley and Mody, 1992; Wolfart et al., 2005; Meier et al., 2015). There are few but notable differences between the iKA mouse model and the human condition. Human GCs lack the $\mathrm{GABA}_{\mathrm{A}}$ leak increase and instead show an HSrelated enhancement of ZD7288-sensitive, hyperpolarizationactivated cation conductance, most likely mediated by $\mathrm{HCN} 1$ channels (Stegen et al., 2012). Thus, contrary to prior reports (Stabel et al., 1992), a functional h-current $\left(\mathrm{I}_{\mathrm{H}}\right)$ exists in rodent and human GCs (Young et al., 2009; Stegen et al., 2012) and this $\mathrm{I}_{\mathrm{H}}$, as well as respective $\mathrm{HCN} 1$ subunits are enhanced in HS-related TLE (Bender et al., 2003; Stegen et al., 2012). The functional effect of $I_{H}$ in GCs is similar to the $G_{A B A}$ leak because $\mathrm{E}_{\mathrm{H}}$ is also between $\mathrm{V}_{\text {rest }}$ and AP threshold, again contributing to enhanced shunting inhibition (Stegen et al., 2012) (see CA Section for more discussion on HCN channels). Another interesting difference between the GCs of TLE patients and iKA mice is that human GCs almost never display a pronounced delay of AP responses as their iKA counterparts (Stegen et al., 2009, 2012; Young et al., 2009). These "ramp" delays of GCs are mediated by shaker-related, voltage-gated $\mathrm{K}\left(\mathrm{K}_{\mathrm{v}} 1\right)$ channels containing $\mathrm{K}_{\mathrm{v}} 1.1, \mathrm{~K}_{\mathrm{v}} 1.2$, or $\mathrm{K}_{\mathrm{v}} 1.6$ subunits, 
which are sensitive to dendrotoxin and $\mu \mathrm{M}$ concentrations of 4aminopyridine (4-AP) (Kirchheim et al., 2013). The molecular mechanism for the 3-fold delayed AP responses of iKA GCs is transcriptional upregulation of $\mathrm{K}_{\mathrm{v}} 1.1$ subunits, which, consistent with a homeostatic response, is reversible upon interruption of chronic hyperexcitation (Kirchheim et al., 2013). Without these $\mathrm{K}_{\mathrm{v}} 1$ currents, GCs are much more vulnerable during excitotoxic insults (Kirchheim et al., 2013). The dissimilarities between human and mouse GCs could be due to species differences or (more likely) due to the disease etiology. However, for the present perspective on AED strategies it is notable that in both human and mouse TLE GCs, a depolarizing but shunting conductance is co-upregulated with $\mathrm{K}_{\mathrm{ir}}$ channels such that $\mathrm{V}_{\text {rest }}$ is almost unchanged (Stegen et al., 2009, 2012; Young et al., 2009). This downscaling is not only suitable to maintain basic metabolic functions dependent on $\mathrm{V}_{\text {rest }}$; it is also a native example of static shunt, enforcing a subtractive gain shift of the neuronal input-output curve (Wolfart et al., 2005). A recent network simulation study has demonstrated that the experimentally observed channel scaling of GCs could also restore spatiotemporal pattern separation under epileptic conditions, i.e., maintain the proposed function of the DG network (Yim et al., 2015).

In addition to the discussed leak channel modifications, other epilepsy-related changes occur in excitatory ion channels and ionotropic receptors of DG cell types (Table 1). For example, voltage-gated $\mathrm{Ca}\left(\mathrm{Ca}_{\mathrm{v}}\right)$ channels of $\mathrm{P} / \mathrm{Q}$-type $\left(\mathrm{Ca}_{\mathrm{v}} 2.2\right)$ were found increased while the L-type subunit $\mathrm{Ca}_{\mathrm{v}} 1.2$ was diminished in the DG molecular layer of TLE patient vs. autopsy samples (Djamshidian et al., 2002). No such changes were observed in the TLE model of ventricular KA injection (Westenbroek et al., 1998). Many immunohistochemistry studies exist on $G_{A B A} R$ and $\mathrm{GABA}_{\mathrm{B}} \mathrm{R}$ changes during TLE: the $\mathrm{GABA}_{\mathrm{A}} \mathrm{R} \alpha 1-3, \beta 2-$ 3 , and $\gamma 2$ subunits were all found elevated in GCs of TLE patients (Loup et al., 2000) and similar results (except $\alpha 2$ ) were obtained in the iKA model (Bouilleret et al., 2000; Knuesel et al., 2001). In sPilo, the DG immunostaining of $\mathrm{GABA}_{\mathrm{A}} \mathrm{R}$ subunits is heterogeneous (Brooks-Kayal et al., 1998). Some of the confusion, created by various tissue-level studies was clarified by electron microscopy and functional analysis. For example, Sun et al. (2007) revealed that although $\mathrm{GABA}_{\mathrm{A}} \propto 4$ subunits are reduced extrasynaptically in GCs of the hKindl model, they are in fact increased in synaptic locations which was interpreted as proepileptic. Similarly, $\mathrm{GABA}_{\mathrm{A}} \gamma 2$ subunits disappear from synaptic locations, reducing the phasic inhibition in sPilo but they reappear in extrasynaptic locations, apparently replacing lost $\mathrm{GABA}_{\mathrm{A}} \delta$ subunits because functionally, tonic inhibition is maintained (Zhang et al., 2007). Measuring surface-coupled protein during sPilo yielded reduction of $\mathrm{GABA}_{\mathrm{A}} \beta 2 / 3 \gamma 2$ subunits on GC membranes; however, GC recordings revealed that tonic $\mathrm{GABA}_{\mathrm{A}}$ currents were, if anything, increased (Goodkin et al., 2008). In contrast to $\mathrm{GABA}_{\mathrm{A}} \mathrm{Rs}$, the $\mathrm{GABA}_{\mathrm{B}} \mathrm{R} 1 \mathrm{a}-\mathrm{b}$ immunosignal of GCs was found reduced in HS-TLE patients (Munoz et al., 2002).

Interneurons of the DG degenerate in the hilus and the molecular layer but somatic inhibition of GCs is apparently spared (Magloczky and Freund, 2005). Here we refrain from reviewing TLE-related interneuron numbers, as respective cell counting studies mostly rely on $\mathrm{Ca}$ binding proteins which themselves change in TLE as shown by Magloczky et al. (1997); for review see Magloczky and Freund (2005). With respect to ion channels of interneurons in the hilus, a decrease of voltagegated $\mathrm{Na}$ type $1\left(\mathrm{Na}_{\mathrm{V}} 1\right)$ channels (Qiao et al., 2013) and an increase of $\mathrm{Ca}_{\mathrm{v}} 1$ channels (Xu et al., 2007) had been reported. Interestingly, in basket cell interneurons of the $\mathrm{DG}$, tonic $\mathrm{GABA}_{\mathrm{A}}$ currents are homeostatically adjusted in sPilo rats ( $\mathrm{Yu}$ et al., 2013).

Astrocytes may also play an important role in epilepsy, in particular via their (potentially impaired) capacity to buffer extracellular K ions (Bordey and Sontheimer, 1998; Jabs et al., 2008; Boison, 2012). For example, in the DG, less glial $K_{i r}$ current was measured in HS- vs. noHS TLE tissue (Hinterkeuser et al., 2000) and less $K_{2 P} 3.1$-positive glia was noted in the molecular layer (Kim et al., 2008b). Concerning the Kir channels, it is likely that downregulation of the $\mathrm{K}_{\mathrm{ir}} 4.1$ subunit is responsible (Buono et al., 2004; Heuser et al., 2012). However, in another sPilo study, no changes of hippocampal $\mathrm{K}_{\mathrm{ir}} 4.1$ protein were detected or even upregulation was noted in cortical and subcortical regions (Nagao et al., 2013). In a different model (seizure-sensitive gerbils), upregulation of $\mathrm{K}_{2 \mathrm{P}} 3.1$ channels was reported (Kim et al., 2007a). In two human cases, gain of function mutation in the glial $\mathrm{K}_{\mathrm{ir}} 4.1$ channel was associated with infantile epileptic spasms (Sicca et al., 2011).

In summary, pro- and anticonvulsive channel changes have been described in the DG of different TLE models. For noHS models, it is difficult to draw a final conclusion on channel changes in GCs as these are heterogeneous. In TLE tissue with HS, the ion channel expression of GCs is clearly changed to decreased excitability.

\section{Cornu Ammonis}

A prominent example of acquired channelopathy is the reduced influence of A-type (rapidly inactivating) $\mathrm{K}$ channels in dendrites of CA1 PCs of sPilo rats (Bernard et al., 2004). The respective identification as A-type current was performed in current-clamp experiments via $5 \mathrm{mM}$ 4-AP (Bernard et al., 2004), which blocks delayed rectifier (not rapidly inactivating) $\mathrm{K}_{\mathrm{v}} 1$ channels as well as A-type $K_{v} 4$ and $K_{v} 1$ channels (Pongs, 1992). In addition, a reduction of $\mathrm{K}_{\mathrm{v}} 4.2$ and $\mathrm{K}_{\mathrm{v}} 1.4$ mRNA was detected via RT-PCR from microdissected CA1 tissue with mixed cell types (Bernard et al., 2004). The conclusion that $\mathrm{K}_{\mathrm{v}} 4.2$ channel downregulation mediated the dendritic channelopathy in sPilo rats (Bernard et al., 2004) was confirmed later by immunocytochemistry, although quantification on the tissue level yielded no difference in the chronic phase (Monaghan et al., 2008). In another sPilo study, $\mathrm{K}_{\mathrm{v}} 4.2$ protein of the CA1 region was increased during the first week after SE but decreased in the chronic phase (Su et al., 2008). In the sKA model, $\mathrm{K}_{\mathrm{v}} 4.2$ mRNA was reported unchanged in CA1 PCs in the first $24 \mathrm{~h}$ but appeared upregulated $12 \mathrm{~h}$ later (Francis et al., 1997). In the same model, A-currents of CA1 PCs were decreased but their sensitivity to $50 \mu \mathrm{M} 4$-AP and the immunohistochemistry suggested that these currents were rather mediated by $K_{v} 1$ than $K_{v} 4$ channels (Sosanya et al., 2014). 
TABLE 1 | lon channel changes during temporal lobe epilepsy.

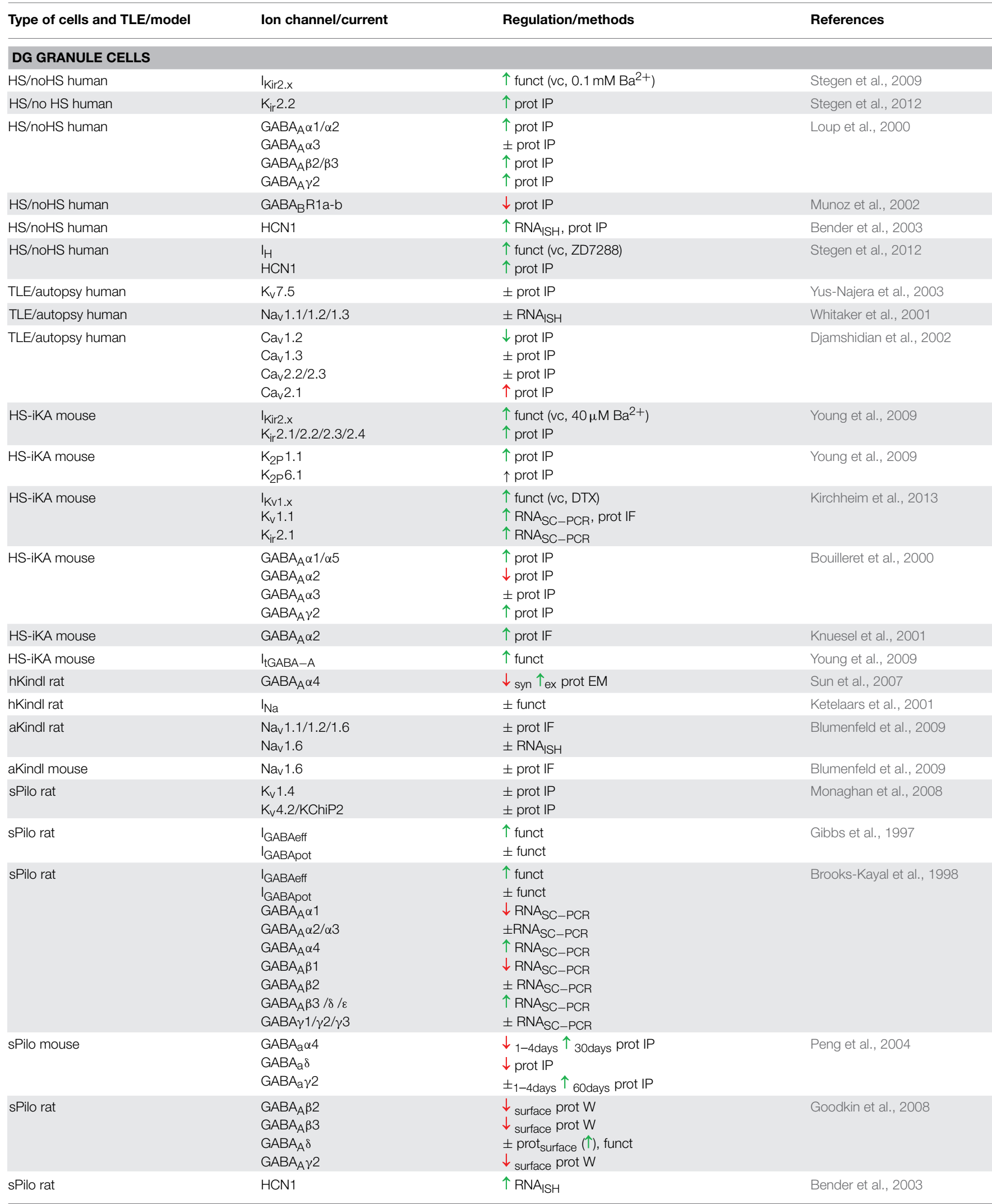


TABLE 1 | Continued

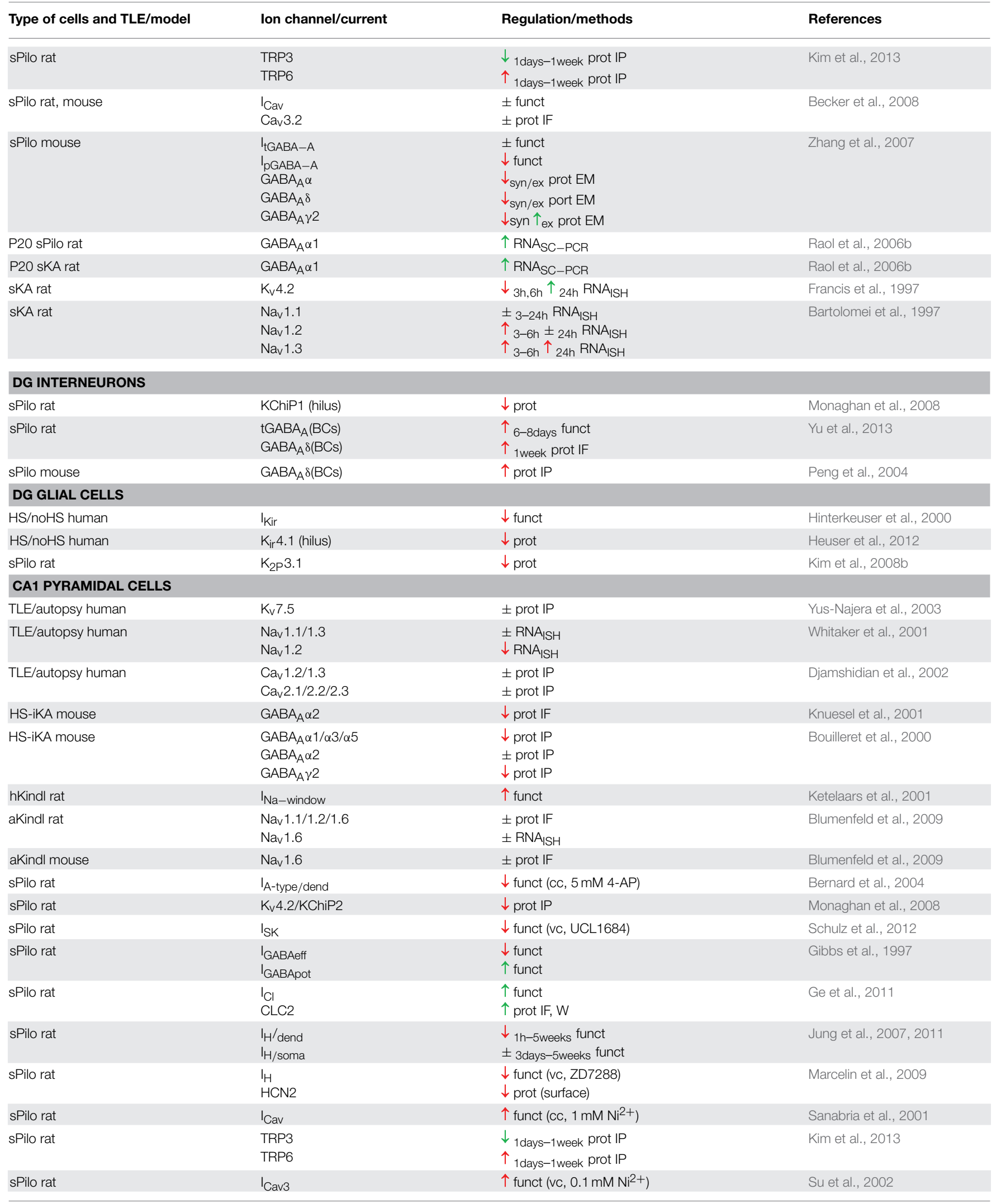


TABLE 1 | Continued

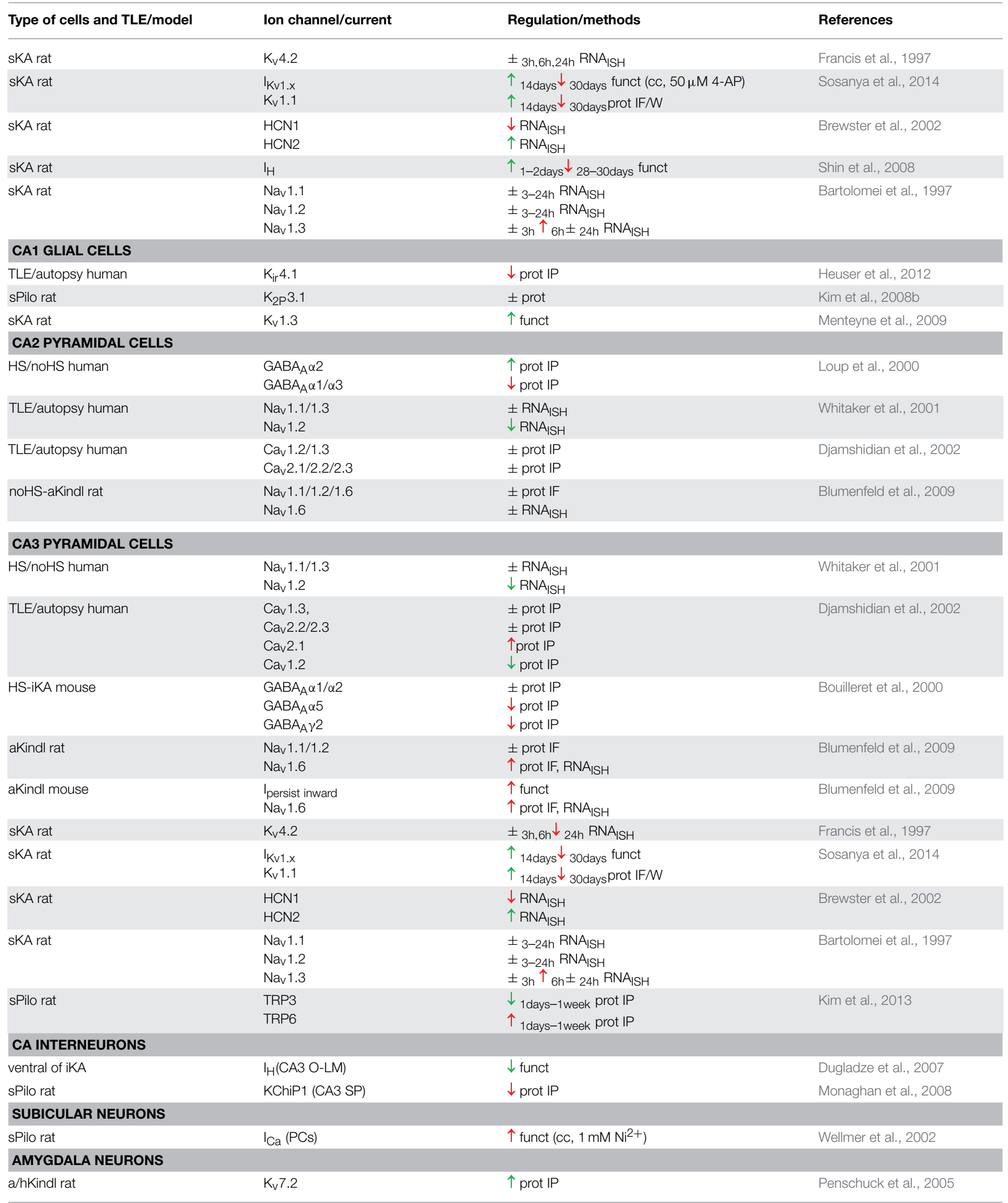


TABLE 1 | Continued

\begin{tabular}{|c|c|c|c|}
\hline Type of cells and TLE/model & lon channel/current & Regulation/methods & References \\
\hline \multicolumn{4}{|l|}{ CORTICAL NEURONS } \\
\hline hKindl rat EC & $\begin{array}{l}\text { INav (layer II stellate cells) } \\
\mathrm{Na}_{\mathrm{v}} 1.2 / 6 \text { (layer II stellate cells) } \\
\mathrm{Na}_{\mathrm{v}} 1.1 / 3 \text { (layer II stellate cells) }\end{array}$ & $\begin{array}{l}\uparrow \text { funct } \\
\uparrow \text { prot IF } \\
\pm \text { prot IF }\end{array}$ & Hargus et al., 2013 \\
\hline hKindl rat PC & $\mathrm{K}_{\mathrm{v}} 1.6$ (interneurons) & $\downarrow$ funct, prot IF & Gavrilovici et al., 2012 \\
\hline sKA rat EC & $\mathrm{I}_{\mathrm{H}}$ (layer III PCs) & $\downarrow_{24 h} \downarrow_{1 \text { week }}$ funct (dendritic) & Shah et al., 2004 \\
\hline sPilo mouse & $\begin{array}{l}\mathrm{I}_{\mathrm{A}} \text { (VM relay cells) } \\
\mathrm{K}_{\mathrm{v}} 4.2 \text { (surf) }\end{array}$ & $\begin{array}{l}\uparrow \text { funct } \\
\uparrow \text { prot IF }\end{array}$ & Smith et al., 2012 \\
\hline sPilo mouse & $\begin{array}{l}\text { IT-Type (relay cells) } \\
\text { Cav3.1 (thalamus) } \\
\text { Cav3.2 (thalamus) } \\
\text { Cav } 3.3 \text { (thalamus) }\end{array}$ & $\begin{array}{l} \pm 4 \mathrm{~h} \uparrow \text { 10days } \uparrow \text { 31days funct } \\
\pm 4 \mathrm{~h} / 1 \text { days } 31 \text { days } \mathrm{RNAPCR} \\
\pm 4 \mathrm{~h} \uparrow \text { 10days } \uparrow \text { 31days RNAPCR } \\
\pm 4 \mathrm{~h} \uparrow \text { 10days } \pm \text { 31days } \mathrm{RNAPCR}\end{array}$ & Graef et al., 2009 \\
\hline TLE/autopsy human & CLC2 (temporal lobe) & $\downarrow R N A_{P C R}$ & Bertelli et al., 2007 \\
\hline HS-iKA mouse & $\mathrm{K}_{\mathrm{ir}} 3.2$ (DG ML) & $\downarrow$ prot IP & Young et al., 2009 \\
\hline sKA rat & $\mathrm{HCN1/2}$ (EC) & $\downarrow_{24 h}=1$ week $\operatorname{prot} W$ & Shah et al., 2004 \\
\hline sKA rat & $\begin{array}{l}\text { HCN1 (CA1) } \\
\text { HCN2 (CA1) }\end{array}$ & $\begin{array}{l}\uparrow 1-2 \downarrow 28-30 \text { days } \text { prot } \mathrm{W} \\
\pm 1-2 \text { days } \downarrow 28 \text {-30days } \text { prot } \mathrm{W}\end{array}$ & Shin et al., 2008 \\
\hline sKA rat & $\begin{array}{l}\text { HCN1 (CA1/DG) } \\
\text { HCN1 (CA3) } \\
\text { HCN1 (EC) } \\
\text { HCN2 (CA1) } \\
\text { HCN2 (CA3) } \\
\text { HCN2 (DG) } \\
\text { HCN2 (EC) }\end{array}$ & $\begin{array}{l} \pm 24 \mathrm{~h} \downarrow 7 \text { days/6weeks RNAPCR } \\
\pm 24 \mathrm{~h} \downarrow 7 \text { days } \pm \text { wweeks RNAPCR } \\
\pm 24 \mathrm{~h} / 7 \text { days/6weeks RNAPCR } \\
\downarrow 24 \mathrm{~h} / 7 \text { days/6weeks RNAPCR } \\
\downarrow 24 \mathrm{~h} \pm 7 \text { days/6weeks RNAPCR } \\
\downarrow 24 \mathrm{~h} \pm 7 \text { days } \downarrow \text { 6weeks RNAPCR } \\
\downarrow 24 \mathrm{~h} \pm 7 \text { days/6weeks RNAPCR }\end{array}$ & Powell et al., 2008 \\
\hline sPilo rat & $\begin{array}{l}\mathrm{K}_{2 \mathrm{P}} 5.1 \text { (CA1) } \\
\mathrm{K}_{2 \mathrm{P}} 5.1 \text { (CA3) } \\
\mathrm{K}_{2 \mathrm{P}} 5.1(\mathrm{DG})\end{array}$ & $\begin{array}{l}\downarrow \text { 3days }-5 \text { weeks prot IF (cell loss) } \\
\uparrow \text { 3days-5weeks prot IF } \\
\uparrow \text { 3days-5weeks prot IF }\end{array}$ & Kim et al., 2009 \\
\hline sPilo rat & $\begin{array}{l}\text { SK1/2 (hipp) } \\
\text { SK3 (hipp) } \\
\text { SK1 (hipp) } \\
\text { SK2/3 (hipp) }\end{array}$ & $\begin{array}{l}\downarrow 10 \text { days } \pm \text { chronic prot } \mathrm{W} \\
\downarrow \text { prot } \mathrm{W} \\
\pm \mathrm{RNAPCR} \\
\downarrow \mathrm{RNAPCR}\end{array}$ & Oliveira et al., 2010 \\
\hline sPilo rat & $\begin{array}{l}\text { SK1/2/3 (CA1) } \\
\text { SK2 (CA1) } \\
\text { SK1/3 (CA1) }\end{array}$ & $\begin{array}{l}\downarrow R N A P C R \\
\downarrow \operatorname{prot} W \\
\pm \operatorname{prot} W\end{array}$ & Schulz et al., 2012 \\
\hline sPilo rat & BK (hilus/CA3) & $\downarrow$ prot IF/W & Pacheco Otalora et al., 2008 \\
\hline sPilo rat & $\begin{array}{l}\text { HCN1 (CA1) } \\
\text { HCN2 (CA1) }\end{array}$ & $\begin{array}{l}\downarrow 3,6 \text { days } \downarrow \text { 3-5weeks prot } \mathrm{W} \\
\downarrow 3,6 \text { days } \pm 3 \text {-5weeks } \text { prot } \mathrm{W}\end{array}$ & Jung et al., 2007 \\
\hline sPilo rat & HCN1 (CA1) & $\downarrow R N A_{P C R}$ & Marcelin et al., 2009 \\
\hline sPilo rat & $\begin{array}{l}\text { HCN1 (CA1-3/DG) } \\
\text { HCN2 (CA1) } \\
\text { HCN2 (CA2/3) } \\
\text { HCN2 (DG) } \\
\text { HCN4 (CA1-3/DG) }\end{array}$ & $\begin{array}{l}\uparrow 12 \mathrm{~h} \pm 2 \text { weeks } \uparrow 11 \text { weeks prot IP } \\
\downarrow 12 \mathrm{~h} \pm 7 \text { days } \downarrow 5 \text { weeks } \text { prot IP } \\
\pm 12 \mathrm{~h}-5 \text { weeks prot IP } \\
\downarrow 12 \mathrm{~h}-5 \text { weeks } \text { prot IP } \\
\pm 12 \mathrm{~h}-5 \text { weeks } \text { prot IP }\end{array}$ & Oh et al., 2012 \\
\hline
\end{tabular}


TABLE 1 | Continued

\begin{tabular}{|c|c|c|c|}
\hline Type of cells and TLE/model & Ion channel/current & Regulation/methods & References \\
\hline sPilo rat & $\begin{array}{l}\mathrm{K}_{\mathrm{ir}} 2.1 \text { (amyg, hipp, ctx) } \\
\mathrm{K}_{\mathrm{ir}} 4.1 \text { (hipp) } \\
\mathrm{K}_{\mathrm{ir}} 4.1 \text { (amyg, striat, ctx) } \\
\mathrm{K}_{\mathrm{ir}} 5.1 \text { (amyg, hipp, ctx) }\end{array}$ & $\begin{array}{l} \pm \text { prot } \mathrm{W} \\
\pm \text { prot } \mathrm{W} \text { IP } \\
\uparrow \operatorname{prot} \mathrm{W} \text { IP } \\
\pm \operatorname{prot} \mathrm{W}\end{array}$ & Nagao et al., 2013 \\
\hline sPilo rat /mouse & Cav3.2 (CA1) & $\uparrow 5_{\text {days }} \pm$ chronic $R N A_{P C R}$, prot $W$ & Becker et al., 2008 \\
\hline sPilo mouse & $\begin{array}{l}\text { Cav3.1 (hippocampus) } \\
\text { Cav3.2 (hippocampus) } \\
\text { Cav3.3 (hippocampus) }\end{array}$ & $\begin{array}{l} \pm 1 \text { ddays } / 31 \text { days } R N A P C R \\
\pm 1 \text { days } \downarrow \text { 31days RNAPCR } \\
\pm 1 \text { ddays/31days RNAPCR }\end{array}$ & Graef et al., 2009 \\
\hline noHS-aKindl rat & $\begin{array}{l}\text { HCN1 (CA1/3/DG/EC) } \\
\text { HCN2 (CA1/DG/EC) } \\
\text { HCN2 (CA3) }\end{array}$ & $\begin{array}{l} \pm_{\text {partial/full }} R N A_{P C R} \\
\pm \text { partial/full } R N A_{P C R} \\
\pm \text { partial } \downarrow \text { full } R N A_{P C R}\end{array}$ & Powell et al., 2008 \\
\hline VKA rat & $\begin{array}{l}\text { Cav1.2/1.3 (CA1-3/DG) } \\
\text { Cav2.1/2.2 (CA1-3/DG) } \\
\text { Cav } \alpha 2 \text { (CA3 astrocyt) }\end{array}$ & $\begin{array}{l} \pm \text { prot IP } \\
\pm \text { prot IP } \\
\uparrow \text { prot IP }\end{array}$ & Westenbroek et al., 1998 \\
\hline
\end{tabular}

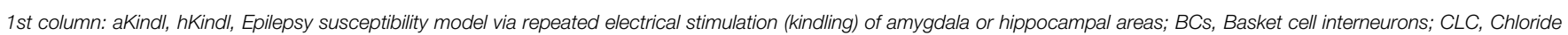

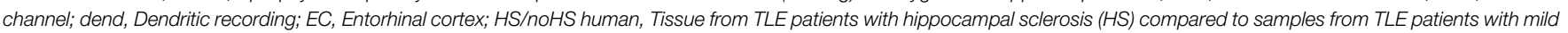

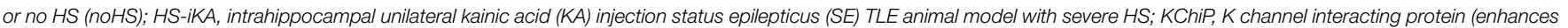

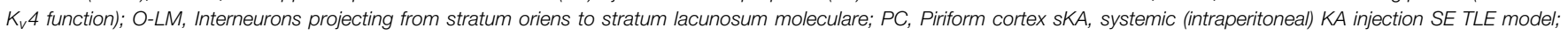

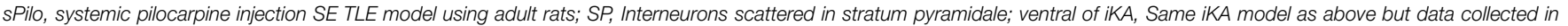

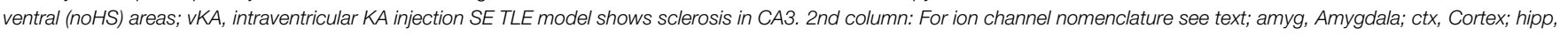

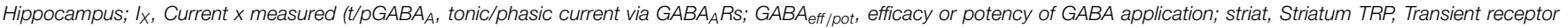

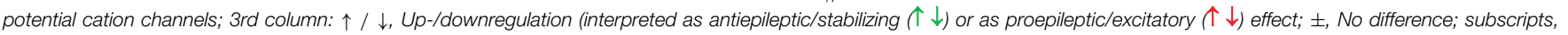

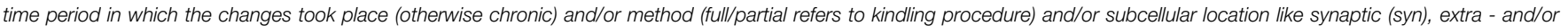

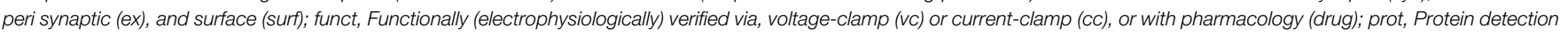

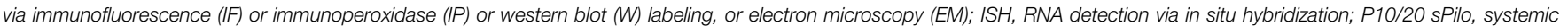

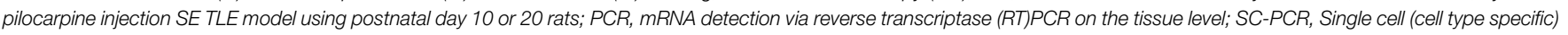
RT-PCR.

In contrast to the sPilo rats, tissue from TLE patients with HS displays similar hippocampal $\mathrm{K}_{\mathrm{v}} 4.2$ mRNA levels compared to patients without $\mathrm{HS}$, and on the protein level $\mathrm{K}_{\mathrm{v}} 4.2$ channels are even elevated, despite the cell loss in the CA1 region (Aronica et al., 2009). In a model of cortical heterotopia, $K_{v} 4.2$ channels are also elevated in CA1 PCs (Castro et al., 2001). In other epilepsy models, $\mathrm{K}_{\mathrm{v}} 4.2$ changes were transient (Tsaur et al., 1992) or increased in the chronic phase (Pei et al., 1997) and also $\mathrm{K}_{\mathrm{v}} 1.2$ levels renormalize after the acute phase (Tsaur et al., 1992; Pei et al., 1997). Genetic deletion of $K_{v} 4.2$ alone is not sufficient to create epilepsy (Hu et al., 2006) which may be due to compensatory mechanisms.

A second prominent channelopathy scenario for TLE also takes place in the distal dendrites of CA1 PCs: downregulation of HCN channels (Bender and Baram, 2007; Dyhrfjeld-Johnsen et al., 2009; Baruscotti et al., 2010; Noam et al., 2011). Opposite to the described increase in DG GCs, HCN1 channels are decreased in CA1 PCs of both sPilo and sKA rats (Jung et al., 2007; Marcelin et al., 2009; Jung et al., 2011). On the tissue level, upregulation of HCN1 was observed in the CA1-3 regions of sPilo, but it was speculated that this staining could have been due to interneurons (Oh et al., 2012). The HCNmediated ZD7288-sensitive h-current has a shunting effect not only in DG GCs (Stegen et al., 2012) but also in CA1 PCs (Gasparini and Difrancesco, 1997; Magee, 1999; Berger et al., 2001). Consequently, loss of $\mathrm{HCN}$ is usually interpreted as proepileptic (Brewster et al., 2002; Poolos et al., 2002; Jung et al., 2007, 2011; Marcelin et al., 2009). However, there are situations, e.g., in febrile seizure models, where an increase of $\mathrm{I}_{\mathrm{H}}$ in CA1 PCs was interpreted as proepileptic (Chen et al., 2001; Poolos, 2004, 2009; Dyhrfjeld-Johnsen et al., 2008, 2009; Noam et al., 2011). Similar to the A-type channelopathy, the HCN channelopathy of noHS models could so far not be confirmed with human data (Bender et al., 2003). In patients with mild HS, abundant $\mathrm{HCN} 1$ protein decorates the distal dendrites of surviving CA1 PCs (Stegen et al., 2012). Similar to $\mathrm{K}_{\mathrm{v}} 4$ channels, HCN1 loss in CA1 PCs alone does not produce epilepsy, but it can enhance the susceptibility for certain seizure induction protocols (Huang et al., 2009; Poolos, 2009; Santoro et al., 2010).

Other ion channel modifications in CA1 PCs include an enhanced $\mathrm{Ca}_{\mathrm{v}}$ channel function in the sPilo, determined with $0.1 \mathrm{mM}$ nickel (Sanabria et al., 2001; Su et al., 2002). This concentration inhibits $\mathrm{Ca}_{\mathrm{v}} 2.3$ (R-type) and $\mathrm{Ca}_{\mathrm{v}} 3$ (T-type) channels. The $\mathrm{Ca}_{\mathrm{v}} 3.2$ RNA from homogenized tissue was indeed found elevated in sPilo, but only in the acute phase and not in the chronic phase (Becker et al., 2008). Another sPilo study detected no changes or even downregulation of $\mathrm{Ca}_{\mathrm{v}} 3$ RNA, but also only on the tissue level (Graef et al., 2009). Concerning Ltype channels $\left(\mathrm{Ca}_{\mathrm{v}} 1.2, \mathrm{Ca}_{\mathrm{v}} 1.3\right)$, P-type $\left(\mathrm{Ca}_{\mathrm{v}} 2.1\right)$, N-type channels $\left(\mathrm{Ca}_{\mathrm{v}} 2.2\right)$, and R-type $\mathrm{Ca}_{\mathrm{v}}$ channels, no immunocytochemistry differences were detected in CA1 PCs of TLE vs. autopsy samples (Djamshidian et al., 2002). Kindled rats displayed an increased window current in CA1 PCs mediated by $\mathrm{Na}_{\mathrm{v}}$ channels at $\mathrm{V}_{\text {rest }}$ (Ketelaars et al., 2001). These differences appeared unlikely to arise from $\mathrm{Na}_{\mathrm{v}} 1.1, \mathrm{Na}_{\mathrm{v}} 1.2$, and $\mathrm{Na}_{\mathrm{v}} 1.6$ channels, as their immuno signal was not changed under similar conditions (Blumenfeld et al., 2009). In contrast, a lowered amount of $\mathrm{Na}_{\mathrm{V}}$ 1.2 RNA was found via in situ hybridization in human TLE 
vs. autopsy samples (Whitaker et al., 2001). Small conductance, Ca-activated $\mathrm{K}$ (SK) channels mediating the medium duration afterhyperpolarization (AHP) appeared reduced in CA1 PCs of sPilo rats and this phenomenon corresponded to a reduction of the SK2 RNA amount on the tissue level (Schulz et al., 2012). Another sPilo study found transient changes in SK1 and SK2 protein and permanent downregulation of SK3 via western blotting of homogenized hippocampus (Oliveira et al., 2010). In a maximal electroshock convulsions (MES) model, no changes were detected in $\mathrm{K}_{\mathrm{v}} 1.1 / 2 / 4, \mathrm{~K}_{\mathrm{v}} 4.2$, and $\mathrm{K}_{\mathrm{ir}} 3.1 / 2$ channels of CA1 PCs (Pei et al., 1997). In seizure-sensitive gerbils, CA1 PCs displayed elevated $\mathrm{K}_{\mathrm{v}} 3.1 \mathrm{~b}$ and $\mathrm{K}_{\mathrm{v}} 3.2$ channel immuno signals (Lee et al., 2009).

The PCs of CA2 and CA3 (in particular CA3a/b) are notably less affected by HS-related cell death than CA1 PCs (Wyler et al., 1992; Blümcke et al., 2012). In samples from TLE patients vs. autopsy, CA3 PCs exhibited increased immunoreactivity for $\mathrm{Ca}_{\mathrm{v}} 2.1$ subunits (Djamshidian et al., 2002). In the same work, the $\mathrm{Ca}_{\mathrm{v}} 1.2$ was diminished in CA3 PCs, but enhanced in astrocytes. The $\mathrm{Na}_{\mathrm{v}} 1.2$ RNA signal was reduced (Whitaker et al., 2001) while the $\mathrm{Ca}_{\mathrm{v}} 2.1$ immuno signal was elevated in CA3 PCs of HS-TLE patients vs. autopsy (Djamshidian et al., 2002). In noHS models, the RNA and immuno intensities of $\mathrm{Na}_{\mathrm{v}} 1.6$ channels were found raised in CA3 PCs (Blumenfeld et al., 2009) while those of $\mathrm{K}_{\mathrm{v}} 4.2$ and $\mathrm{K}_{\mathrm{v}} 1.1$ channels were decreased, respectively (Francis et al., 1997; Sosanya et al., 2014). Because chronic $\mathrm{Na}_{\mathrm{v}}$ upregulation could lead to depolarization block, functional verification is warranted (Auvin et al., 2008; Cestele et al., 2008). The HCN1 RNA was diminished in CA3 PCs of sKA rats, but not after febrile seizures; the HCN2 appeared elevated in both seizure forms, although some of these signals are transient and may be due to interneurons (Brewster et al., 2002). In the MES model, CA cells show little changes in the tested $\mathrm{K}_{\mathrm{v}} 1, \mathrm{~K}_{\mathrm{v}} 4$, and $\mathrm{K}_{\mathrm{ir}} 3$ channels (Pei et al., 1997) while in an absence epilepsy model CA3 PCs displayed upregulation of some $\mathrm{Na}_{\mathrm{v}}$ channels (Xu et al., 2013b). With respect to HS-related iKA seizures, CA3a/b PCs appear similar to DG GCs, i.e., high $\mathrm{K}_{\mathrm{ir}} 2$ levels are found in surviving cells (Young et al., 2009). Thus, more functional characterizations of CA3 cell subtypes in relation to different seizure phenotypes are needed. Also, CA interneurons display ion channel changes in TLE. For example, the oriens-lacunosum moleculare interneurons ventral of the HS area in iKA mice possess reduced $\mathrm{I}_{\mathrm{H}}$ and show increased oscillatory activity in the gamma frequency (Dugladze et al., 2007).

In summary, also in the CA regions, pro- and antiepileptic channel changes have been described in TLE. In comparison with DG GCs, particularly the CA1 PCs stand out with proepileptic changes, as here the two most prominent examples of acquired channelopathy have been described. However, in resected tissue of TLE patients no hyperexcitability was detected in CA1 (Cohen et al., 2002). Thus, the CA1 PC-based acquired channelopathy hypothesis either has to be limited for TLE models without HS or it has to be demonstrated that CA1 PCs in non-sclerotic areas of TLE patients are intrinsically hyperexcitable and/or that surviving hyperexcitable CA1 PCs within the sclerotic hippocampus are connected in a hub-like manner (Morgan and Soltesz, 2008). In its current form, the CA1 PC channelopathy hypothesis collides with the simple principle "dead cells do not seize" (Delorenzo et al., 2005).

\section{Beyond the Hippocampus}

Although the entorhinal cortex is a likely source of TLE seizures (Spencer and Spencer, 1994; Spencer, 2002), it received less attention compared to the hippocampus. Nevertheless, there is evidence for ion channel alterations in this region. For example, in layer III PCs of sKA rats, the $\mathrm{I}_{\mathrm{H}}$ was found decreased in the chronic phase although western blot signals of $\mathrm{HCN} 1$ and $\mathrm{HCN} 2$ channel subunits were at control level at the same time (Shah et al., 2004). In kindled rats, the neocortical layer II stellate cells display elevated $\mathrm{Na}_{\mathrm{v}}$ currents and $\mathrm{Na}_{\mathrm{v}}$ 1.2/1.6 immunostaining (Hargus et al., 2013). In contrast, a sPilo study found no changes in the intrinsic excitability of layer II PCs and concluded that loss of interneurons was responsible for the elevated perforant path output (Kobayashi et al., 2003). Similarly, $\mathrm{K}_{\mathrm{v}} 1.1$ reduction in cortical interneurons could play a role in some forms of TLE (Li et al., 2012). In frontal lobe epilepsy, layer II/III PCs displayed h-current downregulation (Wierschke et al., 2010). In some forms of cortical epilepsies, the opposite of the above described hippocampal $\mathrm{K}_{\mathrm{v}} 4.2$ channelopathy occurs; here these channels are upregulated suggesting homeostatic adaptation of cortical neurons (Aronica et al., 2009).

Other brain areas connected to the hippocampus also display epilepsy-related ion channel adaptations or pathologies. For example, in the subiculum, increased Ca currents were detected in sPilo (Wellmer et al., 2002) while in kindling models, the amygdala showed elevated levels of KCNQ2 $\left(\mathrm{K}_{\mathrm{v}} 7.2\right)$ channel protein (Penschuck et al., 2005). Two brain areas rarely implicated in TLE, are the substantia nigra (Depaulis et al., 1994; Ma et al., 2007) and the thalamus (Bertram et al., 2001). One sPilo study found elevated T-type currents in thalamic relay cells and consistent $\mathrm{Ca}_{\mathrm{v}} 3$ channel RNA upregulation on the tissue level (Graef et al., 2009). In contrast, the enhanced $K_{v} 4.2$ surface protein expression in ventromedial thalamic relay neurons of sPilo argued for an adaptive response (Smith et al., 2012). We use the thalamus to illustrate that similar ion channels can have opposite functions in different cell types and epilepsies: when sufficiently hyperpolarized, thalamic neurons are capable of rebound burst firing which is mediated by T-type $\left(\mathrm{Ca}_{\mathrm{v}} 3\right)$ channels and thought to underlie absence epilepsy (Budde et al., 2005; Cope et al., 2009; Kanyshkova et al., 2012) although other mechanisms may also play a role (Crunelli and Leresche, 2002; Strauss et al., 2004; Kole et al., 2007). Therefore, it makes sense that absence epilepsy is treated with $\mathrm{Ca}_{\mathrm{v}} 3$ channel inhibitors, while hyperpolarizing AEDs can even aggravate absence seizures (Rogawski and Löscher, 2004; Powell et al., 2014). Bursting of "epileptic neurons" has long been suspected as the cellular correlate of epileptic seizures in general (Sypert and Ward, 1967). Also for TLE, pathological $\mathrm{Ca}_{\mathrm{v}} 3$-supported burst firing has been suggested as a cellular mechanism for seizures (Yaari and Beck, 2002). However, the same T-type channel responsible for epileptic bursting in thalamic and cortical neurons could actually prevent burst firing in other cell types (Wolfart and Roeper, 
2002). Hence, it is important to determine the role of AEDtargeted ion channels in a cell type-specific manner, in particular since current AEDs are applied systemically.

\section{Mechanisms Underlying Epilepsy-Related Ion Channel Alterations}

The molecular upstream links of many of the above described ion channel modifications are unclear. For example, the correlation between HS and the leak channel upregulation in DG GCs currently only allows the statement that some part of the sequence, which leads to HS, must also be responsible for the observed changes in channel transcription. One possibility would be that morphological alterations, e.g., related to cytoskeletal changes as they occur during GCD, directly also cause the channel changes (O'Malley and Harvey, 2007). As GCD is caused by reelin deficiency (Haas et al., 2002), reelin is a candidate molecule and indeed it can affect transcription factors (Feng et al., 1999; Chen et al., 2007). However, the hypothesis requires that reelin deficiency alone (without epilepsy) must also trigger the respective channel changes, which does not appear to be the case (Kowalski et al., 2010). Another possible mechanism for transcriptional channelopathies is that the access to neurotrophic factors is interrupted in areas of injury (Waxman, 2001).

We currently favor the hypothesis that the seizures themselves partially cause HS (Mathern et al., 2002) and that the same seizure-induced mechanisms which cause HS, also cause the ion channel changes. The reasoning is as follows. In animal models, SE-related excitotoxic neurodegeneration has two phases: an acute glutamate receptor overstimulation cell swelling phase, and a late Ca-related phase, which gradually fades into the chronic phase of spontaneous seizures, the latter being associated with permanently disturbed intracellular Ca levels (Olney and Sharpe, 1969; Choi, 1992; Magloczky and Freund, 1995; Delorenzo et al., 2005). Also for the iKA model two phases of HS have been described; in the first phase, i.e., hours after KA injection, CA1 PCs and hilar neurons degenerate; in the second phase, about 2 weeks after KA injection, full HS develops with GCD and neurodegeneration affecting CA1, CA3c PCs and eventually also CA3a/b, CA2 PCs, and DG GCs (Bouilleret et al., 1999). While the initial injury has its own channel changes (see below), the second phase of HS-related neurodegeneration in iKA mice correlates well with the described downscaling GC excitability in the same model (Young et al., 2009). Another argument for the hypothesis "chronic seizures cause chronic channel adaptations" is the evidence showing that activitydependent Ca signals directly couple the degree of excitation to the regulation of gene expression (Marder and Goaillard, 2006). Furthermore, hippocampal seizures are associated with extensive NMDA receptor activation and $\mathrm{Ca}$ influx inducing cell stress and neurodegeneration (Isokawa and Levesque, 1991; Magloczky and Freund, 1995; Golowasch et al., 1999; Limbrick et al., 2003; Raza et al., 2004; Ayala and Tapia, 2005; Suzuki et al., 2005). From what we know about the mechanisms of long term synaptic potentiation (LTP), the NMDA-mediated Cainflux during seizures is likely to activate $\mathrm{Ca}$-dependent kinases (Varga et al., 2004; Nassirpour et al., 2010) and transcription factors, which in turn regulate the transcription of specific ion channel genes (Scharfman, 2002; Fan et al., 2005; Blair et al., 2008; Mucha et al., 2010). This view is also consistent with many homeostasis studies demonstrating how increased neuronal activity can directly influence ion channel expression (Turrigiano et al., 1995; Desai et al., 1999; Van Welie et al., 2004; Misonou et al., 2006). Even the subunit-specific heteromerization can be influenced by seizure-like activity (Zha et al., 2008). Another aspect of epilepsy-related channel regulation is the subject of age. Generally, the immature brain appears more sensitive to seizures than the adult brain (Jensen and Baram, 2000), but chronic epilepsy may develop easier in adult animals (Brooks-Kayal et al., 1998; Zhang et al., 2004; Raol et al., 2006b).

Many mechanistic questions remain. For example: if TLE models without HS show similar elevated input to GCs as HS models (Kobayashi et al., 2003; Kumar and Buckmaster, 2006), why do they not display the same channel changes as HS-TLE models? We would like to know what kind of patterns evoke which type of homeostatic ion channel regulation. There are many molecules modified in HS-related TLE (Becker et al., 2003; Elliott et al., 2003; Lukasiuk and Pitkanen, 2004; Motti et al., 2010; Okamoto et al., 2010). Which of these molecules relates to ion channel transformations? A major question is: if the hypothesis of activity- and Ca-dependent homeostatic channel regulation is true, why are there so few adaptive changes in CA1 PCs (Whitaker et al., 2001; Ge et al., 2011)? One possibility would be that CA PCs have a network task that does not allow such homeostatic adaptations. For example, if activity-dependent LTP strengthens synapses on CA1 PCs, it could be counterproductive if the same activity would weaken synaptic impact. In this context, it makes sense that LTP-inducing mechanisms are accompanied by permissive $\mathrm{K}_{\mathrm{v}}$ channel internalization (Kim et al., 2007b; Hyun et al., 2013) or HCN1 downregulation (Mcclelland et al., 2011). On the other hand, it is unlikely that LTP of CA1 PCs is a positive feedback mechanism that exists without homeostatic ion channel control (Abbott and Nelson, 2000). Astonishingly, the survival rate of CA1 PC cells is even higher in the noHS TLE models where exactly these detrimental mechanisms have been discovered. If noHS TLE would be an early stage of HS TLE, the LTP-permissive channel regulation of CA1 PCs could be even stronger in HS-related TLE and in fact be responsible for the CA1 PC degeneration. Back to the initial question: CA1 PCs are indeed also capable of homeostatic ion channel regulation counteracting chronic hyperexcitability (Van Welie et al., 2004, 2006; Otto et al., 2006). Thus, similar to the interaction of LTP and synaptic depression, there must be mechanisms to separate homeostatic and LTP-permissive ion channel regulation within the same neuron.

In addition to the control of gene transcription, epilepsyrelated changes in ion channel function can be fine-tuned via post-transcriptional mechanisms like splicing and RNA edition, as well as oxidation or phosphorylation. For example, glycine receptors of hippocampi resected from TLE patients show altered RNA editing, which is particularly relevant when combined with abnormal expression of $\mathrm{Cl}$ cotransporter 2 (KCC2) and proconvulsive shift of $\mathrm{E}_{\mathrm{Cl}}$ (Eichler et al., 2008; Meier et al., 2014). Another example is the increased $\mathrm{K}_{\mathrm{v}} 1.1$ RNA editing found in 
sKA rats (Streit et al., 2011). The intracellular redox state is also known to influence ion channel function via post-translational modulation (Ruppersberg et al., 1991) and redox-sensitivity of A-type channels appears to be modified in DG GCs from sPilo rats (Rüschenschmidt et al., 2006). Hypoxia is another stimulus for adaptive ion channel modification. For example, in CA1 PCs, reduced oxygen levels lead to $\mathrm{I}_{\mathrm{H}}$ downregulation within less than an hour (Zhang et al., 2006). Seizure-related pH changes can also affect channel function and vice versa (Ziemann et al., 2008). Furthermore, phosphorylation is a cellular mechanism, not only to regulate protein trafficking but also to dynamically control ion channel gating (Levitan, 1994). For example, the above discussed ( $\mathrm{sKA} \mathrm{K}_{\mathrm{v}} 4$ and sPilo HCN) channelopathies had both been linked to the intracellular phosphorylation status (Lugo et al., 2008; Jung et al., 2010). Finally, reciprocal changes in phosphorylation and methylation of $\mathrm{Na}_{\mathrm{v}}$ channels had been observed with sKA-related seizures (Baek et al., 2014).

Ion channel function depends on the subcellular location to which the channels are targeted and this targeting can be altered in epilepsy (Chung et al., 2006). One example is the subcellular redistribution of dendritic $\mathrm{K}_{\mathrm{v}} 4.2$ channels in sPilo rats from the inner to the outer molecular layer of the DG (Monaghan et al., 2008). Another example is the disturbed HCN channel trafficking into dendrites of CA1 PCs in epilepsy models (Shin et al., 2008). Furthermore, the axon initial segment and presynaptic terminals have been specifically implicated in TLE (Wimmer et al., 2010; Meier et al., 2014). Thus, ion channels are constantly adapted on pre- and post-translational levels and epilepsy interferes with both levels. Nevertheless, it may be possible to separate the channel changes into those which are part of a cure, i.e., homeostatic in nature, and those which are part of the disease, i.e., either straightforward channelopathy or failure of homeostasis. In any case, AEDs must act on the background of these channel changes. In the next chapter we ask which AEDs have mechanisms of actions comparable to the homeostatic channel regulations observed in neurons during TLE.

\section{Ion Channel-Related Antiepileptic Drug and Gene Therapy Mechanisms}

The available AEDs are hypothesized to work via reducing the impact of excitatory ion channels and/or increasing the effect of net inhibitory channels (Löscher et al., 2013). For example, Phenytoin, Carbamazepine, Lamotrigine, Oxcarbazepine, Zonisamide, Rufinamide, Lacosamide, and Eslicarbazepine are thought to act via $\mathrm{Na}$ channels, whereas Ethosuximide, Gabapentin, Pregabalin are Ca channel antagonists. Phenobarbital, Primidone, Diazepam, Clonazepam, Clobazam, Progabide, Vigabatrin, and Tiagabin support inhibition via $\mathrm{GABA}_{\mathrm{A}}$ channels. Other AEDs like Valproate, Felbamate, and Topiramate are effective at multiple of the above targets. There is only one $\mathrm{K}$ channel enhancer AED on the market: the recently approved, first-in-class AED Retigabine (Faulkner and Burke, 2013). Thus, current AEDs mainly target excitatory channels while in contrast, the neurons frequently upregulate K channels when faced with epileptic hyperexcitability
(Table 1). Despite the dissimilar routes of AED mechanisms and cell type-specific homeostasis, some of the cellular strategies are indeed comparable to (potential) AED mechanisms (Table 2). More than $100 \mathrm{~K}$ channel subunits are currently known (Coetzee et al., 1999; Goldstein et al., 2005; Gutman et al., 2005; Kubo et al., 2005; Wei et al., 2005) and interaction of native subunits enlarges the number of $\mathrm{K}$ currents that can be considered as potential AED targets in preclinical research considerably. Therefore, we propose that cell type-specific approaches based on endogenous homeostasis mechanisms, could guide target-driven development of AEDs.

Early studies investigated ATP-sensitive $\mathrm{K}_{\mathrm{ir}}\left(\mathrm{K}_{\mathrm{ir}} 6\right)$ channel openers such as cromakalim and diazoxide as potential AEDs (Alzheimer and Ten Bruggencate, 1988; Gandolfo et al., 1989a,b). These $K_{\text {ir }} 6$ channel enhancers were also found protective in anoxia-induced seizures (Mattia et al., 1994; Yamada et al., 2001). However, because $\mathrm{K}_{\mathrm{ir}} 6$ channels are also expressed in the periphery and because the substances were ineffective in standard AED testing models, $\mathrm{K}_{\mathrm{ir}} 6$ channel activators may be of limited utility for epilepsy therapy (Wickenden, 2002; Meldrum and Rogawski, 2007). Systemic administration of SK channel enhancer EBIO reduces seizures in certain seizure models but also produced severe adverse effects (Anderson et al., 2006). Also, $\mathrm{Cl}$ channels were considered in the context of TLE (Stogmann et al., 2006; Bertelli et al., 2007; Rinke et al., 2010). Retigabine was initially thought to exert its anticonvulsive action only via GABARs (Rostock et al., 1996; Otto et al., 2002). Later it was shown that Retigabine also activates $\mathrm{K}_{\mathrm{v}} 7$ channels, fortunately those of the brain $\left(\mathrm{K}_{\mathrm{v}} 7.2-5\right)$ and not those of the heart $\left(\mathrm{K}_{\mathrm{v}} 7.1\right)$ raising hopes on the new AED class (Main et al., 2000; Rundfeldt and Netzer, 2000; Wickenden et al., 2000; Tatulian et al., 2001; Dost et al., 2004). However, to establish how retigabine and similar related compounds are best used in epilepsy therapy, still has to be determined (Splinter, 2013).

The $\mathrm{K}_{\mathrm{v}} 1.1$ channel subunit has often been implicated in epilepsy (Smart et al., 1998; Wenzel et al., 2007; Robbins and Tempel, 2012). A gene therapy approach showed that viral $\mathrm{K}_{\mathrm{v}} 1.1$ overexpression in neocortical PCs of mice with neocortical epilepsy, effectively reduces the respective seizures (Wykes et al., 2012). A $K_{v} 1.1$ reduction in interneurons was also suggested to play a role in some forms of TLE (Li et al., 2012). Interestingly, precisely the $\mathrm{K}_{\mathrm{V}} 1.1$ subunits are enhanced endogenously in DG GCs of iKA mice with severe HS (Kirchheim et al., 2013) but apparently not in TLE patients with HS (Stegen et al., 2009, 2012). Thus, $K_{v} 1.1$ enhancement in specific hippocampal neurons could be an excellent antiepileptic and neuroprotective strategy (Kirchheim et al., 2013; Sosanya et al., 2014).

A number of drugs, originally approved for a different action, were later found to enhance $\mathrm{K}_{\mathrm{ir}}$ channel function; e.g., $\mathrm{K}_{\mathrm{ir}} 1.1$ (Pregabaline) and $\mathrm{K}_{\mathrm{ir}} 2.3$ (Tenidap; Liu et al., 2002; Lee and Liou, 2014). Furthermore, supporting $\mathrm{K}_{\mathrm{ir}} 3$ channel (Kaufmann et al., 2013) and $\mathrm{K}_{\mathrm{ir}} 2$ channel (Xu et al., 2013a) function in vivo is effective against seizures of certain epilepsy models (Table 2). Finally, $\mathrm{K}_{2 \mathrm{P}} 2.1$ upregulation via adenoviral gene therapy reduces EEG seizures in the sPilo model (Dey et al., 2014). Hence, leak $\mathrm{K}$ channels could be an attractive AED target. Again, especially $\mathrm{K}_{\mathrm{ir}}$ 2.1-2.4 and $\mathrm{K}_{2 \mathrm{P}} 2.1$ leak channels, which are endogenously 
TABLE 2 | Inhibitory ion channel changes with antiepileptic potential.

\begin{tabular}{|c|c|c|c|}
\hline Ion channel & AED, Seizure model & Cell type/Method & References \\
\hline \multicolumn{4}{|c|}{ POTASSIUM CHANNELS } \\
\hline $\mathrm{K}_{2 \mathrm{P}} 2.1 \uparrow$ & GenTher (hip, EC, pre SE)/sPilo & Hip neur recs, CellCult, EEG, behavior & Dey et al., 2014 \\
\hline $\mathrm{K}_{\mathrm{ir}} 1.1 \uparrow$ & Pregabaline/A & Thal neur recs, HetEx & Lee and Liou, 2014 \\
\hline $\mathrm{K}_{\mathrm{ir}} 2.3 \uparrow$ & Tenidap/A* & HetEx recs & Liu et al., 2002 \\
\hline $\mathrm{K}_{\mathrm{ir}} 2.3 \uparrow$ & Tenidap/A*/sPilo & EEG, behavior & Xu et al., $2013 a$ \\
\hline $\mathrm{K}_{\mathrm{ir}} 3.1 \uparrow$ & ML297/MES/PTZ & HetEx recs, behavior & Kaufmann et al., 2013 \\
\hline \multicolumn{4}{|l|}{$\mathrm{K}_{\mathrm{ir}} 3.4 \uparrow$} \\
\hline $\mathrm{K}_{\mathrm{ir}} 6.2 \uparrow$ & Pregabaline/A H19-7 & CellCult hip neur recs & Huang et al., 2006 \\
\hline $\mathrm{K}_{\mathrm{ir}} 6 . \mathrm{x} \uparrow$ & Cromakalim/diazoxide anoxia seizure model & Field recs & Mattia et al., 1994 \\
\hline $\mathrm{K}_{\mathrm{v}} 1.1 \uparrow$ & PTZ & Behavior & Lu et al., 2008 \\
\hline $\mathrm{K}_{\mathrm{v}} 1.1 \uparrow$ & GenTher (neo, post SE)/NCTX iTX & NCTX PC recs, EEG & Wykes et al., 2012 \\
\hline $\mathrm{K}_{\mathrm{V}} 1.1 \uparrow$ & Rapamycin/sKA & Behavior & Sosanya et al., 2014 \\
\hline $\mathrm{K}_{\mathrm{v}} 7.2 / 7.3 \uparrow$ & ICA-27243/MES/PTZ/aKindl & Behavior, HetEx recs, Hip neur recs & Roeloffs et al., 2008; Wickenden et al., 2008 \\
\hline $\mathrm{K}_{\mathrm{v}} 7 . \mathrm{x} ? \uparrow$ & Somatostatin/Gen sPent/sKA & CA1 PCs, field recs, behavior & Qiu et al., 2008 \\
\hline $\mathrm{K}_{\mathrm{v}} 7.2 / 7.3 \uparrow$ & Flupirtine/A*/sKA/FNeo & EEG, behavior & Raol et al., 2009 \\
\hline $\mathrm{K}_{\mathrm{v}} 7.2 / 7.3 \uparrow$ & Retigabine/A & CA3 PCs recs & Kim et al., 2012 \\
\hline $\mathrm{K}_{\mathrm{v}} 7.2 / 7.3 \uparrow$ & Retigabine/A/case & EEG, behavior & Walleigh et al., 2013 \\
\hline $\mathrm{K}_{\mathrm{v}} 7.2 / 7.3 \uparrow$ & Retigabine/A & HetEx recs & Schenzer et al., 2005; Zhou et al., 2013 \\
\hline $\mathrm{K}_{\mathrm{v}} 7.2-7.5 \uparrow$ & ICA-105665 i.p./P2 & EEG, behavior & Kasteleijn-Nolst Trenite et al., 2013 \\
\hline $\mathrm{K}_{\mathrm{v}} \mathrm{Del} \downarrow$ & Lamotrigine/A & CA1 PC recs & Grunze et al., 1998 \\
\hline $\mathrm{K}_{\mathrm{v}} \mathrm{Del} \downarrow$ & Levetiracetam/A & Hip neur recs, CellCult & Madeja et al., 2003 \\
\hline Kv A-type $\downarrow$ & Lamotrigine/A & Hip neur recs, CellCult & Huang et al., 2004 \\
\hline hERG $\downarrow$ & Lamotrigine/APhenytoin/A & HetEx recs & Danielsson et al., 2003, 2005 \\
\hline $\mathrm{KCa}(\mathrm{SK}) \uparrow$ & EBIO/MES, PTZ & Behavior & Anderson et al., 2006 \\
\hline $\mathrm{KCa}(\mathrm{BK}) \uparrow$ & Zonisamide/A H19-7 & Hip neur recs, CellCult & Huang et al., 2007 \\
\hline $\mathrm{KCa} 2 \uparrow$ & SKA-19 i.p./aKindl/in vitro PTX/4-AP & CA1 PC recs & Coleman et al., 2015 \\
\hline \multicolumn{4}{|l|}{$\mathrm{Na}_{\mathrm{V}} \downarrow$} \\
\hline \multicolumn{4}{|c|}{ GABA $_{A}$ RECEPTORS AND OTHER CHLORIDE CHANNELS } \\
\hline $\mathrm{GABA}_{\mathrm{A} \alpha 1} \uparrow$ & GenTher (DG, pre SE)/sPilo & DG, EG, behavior & Raol et al., $2006 a$ \\
\hline $\mathrm{I}_{\mathrm{GABAA}} \uparrow$ & Retigabine/A & Cort neur recs, CellCult & Otto et al., 2002 \\
\hline $\mathrm{ClNpHR} \uparrow$ & Optogenetic act/NCTX iTX & EEG & Wykes et al., 2012 \\
\hline $\mathrm{GABA}_{\mathrm{A} \delta} \uparrow$ & GenTher/CTZ/sKA & CA1 PC recs, behavior & Sun et al., 2013 \\
\hline \multicolumn{4}{|c|}{ HCN CHANNELS } \\
\hline $\mathrm{I}_{\mathrm{H}} \uparrow$ & Lamotrigine/A & CA1 PCs, dendritic recs & Poolos et al., 2002 \\
\hline $\mathrm{I}_{\mathrm{H}} \uparrow$ & Lamotrigine/A & Interneurons (CA1 O-LM?) & Peng et al., 2010 \\
\hline $\mathrm{I}_{\mathrm{H}} \uparrow$ & Gabapentin/A & CA1 PCs & Surges et al., 2003 \\
\hline
\end{tabular}

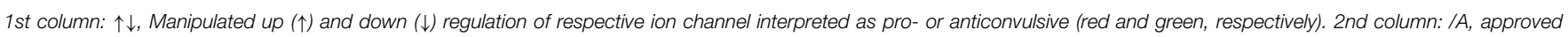

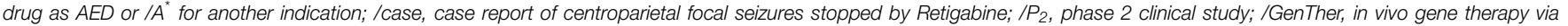

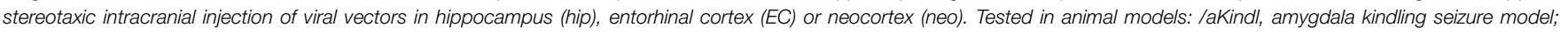
/FNeo, rat model of neonatal seizures via convulsant gas flurothyl; MES, maximal electroshock model of epilepsy; NCTX iTX, motorcortex tetanus toxin injection model of neocortical

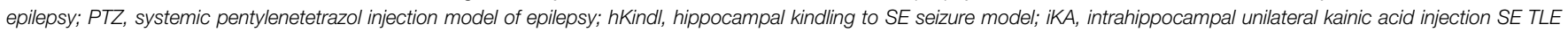

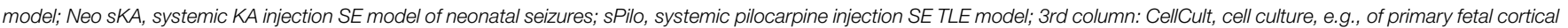

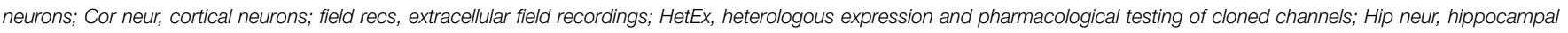
neurons, CI NpHR, chloride pump halorhodopsin from Natronomonas pharaonis, NpHR; recs, electrophysiological recordings; Thal neur, thalamic neurons.

upregulated in DG GCs during epileptic hyperexcitability, appear to be good candidates (Young et al., 2009).

Although enhancing $K$ channel function is a plausible antiepileptic strategy, there are drawbacks. For example, too much silencing via $\mathrm{K}$ channels can also be detrimental (Du et al., 2005; Taverna et al., 2005; Coulson et al., 2008).
Furthermore, as discussed for the thalamus, de-inactivation of $\mathrm{Na}_{\mathrm{v}}$ and $\mathrm{Ca}_{\mathrm{v}}$ channels necessary for $\mathrm{AP}$ activation results in the counterintuitive effect that enhancing $\mathrm{K}$ currents can increase seizure susceptibility. One example is the big conductance, Caactivated $\mathrm{K}(\mathrm{BK})$ channel. These channels contribute to the fast AHP, enabling high AP frequencies. Consequently, enhancing BK 
currents has proepileptic effects (Jin et al., 2000; Brenner et al., 2005; Shruti et al., 2008). If in turn the fast AHP is impaired in interneurons, e.g., via loss of $\mathrm{K}_{\mathrm{v}} 3.2$ channels, seizures become more likely (Lau et al., 2000). Hence, the usability of K channel enhancing AEDs has to be carefully evaluated.

As explained, certain $\mathrm{Cl}$ and cation conductances, mediated by $\mathrm{GABA}_{\mathrm{A}}$ Rs and HCN channels, confer shunting inhibition which may also be used as an AED strategy. Indeed, enhancing tonic $\mathrm{GABA}_{\mathrm{A}}$ currents by overexpression of $\alpha 5 / \beta 3 / \gamma 2$ and $\alpha 6 / \beta 3 / \delta$ GABARs, reduced epileptiform activity in hippocampal cell culture and elevation of the $\delta$ GABARs in vivo lowered cyclothiazide (CTZ)-induced seizures (Sun et al., 2013). Also HCN channels are an AED target which requires further investigation (Poolos et al., 2002; Shah et al., 2013): certain AEDs, initially approved as $\mathrm{Na}_{\mathrm{v}}$ and $\mathrm{Ca}_{\mathrm{v}}$ channel blockers, later turned out be enhancers of $I_{H}$ in CA1 PCs as well (Poolos et al., 2002; Surges et al., 2003). However, since one of them (Lamotrigine) was also effective in interneurons (Peng et al., 2010), further experiments must clarify to which extend $\mathrm{I}_{\mathrm{H}}$ is involved in the mechanisms of action of these AEDs. As explained above, the combination of $\mathrm{K}_{\mathrm{ir}}$ and $\mathrm{HCN} / \mathrm{Cl}$ channel upregulation achieves a homeostatic shunt in GCs during TLE (Young et al., 2009; Stegen et al., 2012). It is tempting to speculate that support of such shunting channel combinations indicated by GCs (which could be called "channelacoids") is a particularly promising AED strategy.

Impaired interneuron activity, e.g., due to $\mathrm{Na}_{\mathrm{v}}$ channel mutations, often increases seizure susceptibility (Lau et al., 2000; Chen et al., 2002; Ogiwara et al., 2007; Martin et al., 2010; Mashimo et al., 2010; Rossignol et al., 2013; De Kovel et al., 2014; Hedrich et al., 2014). Therefore, it makes sense that supporting GABAergic transmission is a successful AED treatment (see above). However, more cell type-specific data is needed to explain how systemically administered AEDs, which block $\mathrm{Na}_{\mathrm{v}}$ channels also expressed in interneurons, actually work. Apparently these AEDs preferentially target excitatory neurons (Prakriya and

\section{References}

Abbott, L. F., and Nelson, S. B. (2000). Synaptic plasticity: taming the beast. Nat. Neurosci. 3(Suppl.), 1178-1183. doi: 10.1038/81453

Alzheimer, C., and Ten Bruggencate, G. (1988). Actions of BRL 34915 (Cromakalim) upon convulsive discharges in guinea pig hippocampal slices. Naunyn Schmiedebergs. Arch. Pharmacol. 337, 429-434. doi: 10.1007/ BF00169535

Anderson, N. J., Slough, S., and Watson, W. P. (2006). In vivo characterisation of the small-conductance $\mathrm{KCa}$ (SK) channel activator 1-ethyl-2benzimidazolinone (1-EBIO) as a potential anticonvulsant. Eur. J. Pharmacol. 546, 48-53. doi: 10.1016/j.ejphar.2006.07.007

Aronica, E., Boer, K., Doorn, K. J., Zurolo, E., Spliet, W. G., Van Rijen, P. C., et al. (2009). Expression and localization of voltage dependent potassium channel Kv4.2 in epilepsy associated focal lesions. Neurobiol. Dis. 36, 81-95. doi: 10.1016/j.nbd.2009.06.016

Auvin, S., Dulac, O., and Vallee, L. (2008). Do SCN1A mutations protect from hippocampal sclerosis? Epilepsia 49, 1107-1108. doi: 10.1111/j.15281167.2008.01549_3.x

Ayala, G. X., and Tapia, R. (2005). Late N-methyl-D-aspartate receptor blockade rescues hippocampal neurons from excitotoxic stress and death
Mennerick, 2000; He et al., 2002; Pothmann et al., 2014). On the other hand, functional enhancement of interneurons can be an effective AED strategy (Jensen et al., 2014). The next question would be how interneurons inhibiting interneurons fit into these scenarios (Kim et al., 2008a). Generally, the specific role of interneuron subtypes in epilepsy is far from clear, in particular when considering that many of the synchronous AP rhythms, generated by interneurons, are suspiciously akin to epileptic seizures (Cobb et al., 1995; Cohen et al., 2002; D’antuono et al., 2004; Vida et al., 2006). Last but not least, it should be kept in mind that all ion channel abnormalities acquired during epilepsy, can affect their sensitivity for AEDs. Indeed, changes in the channel subunit composition are among the mechanisms proposed to underlie acquired pharmacoresistance (Sun et al., 2007; Zhang et al., 2007; Streit et al., 2011). One example would be a decrease of the $\mathrm{K}_{\mathrm{v}} 7.2 / 7.3$ ratio, as suggested by (Otto et al., 2006), which is expected to increase the Retigabine sensitivity of $\mathrm{K}_{\mathrm{v}} 7$ channels (Schenzer et al., 2005).

In summary, cell type-specific information on epilepsyrelated ion channel modifications can explain and support AED strategies. Precisely those inhibitory ion channels which appear to be effective AED targets in preclinical tests are the ones upregulated in DG GCs during TLE. These data indicate that cell-endogenous ion channel homeostasis mechanisms could be used as "channelacoid" archetypes in the search of antiepileptic strategies. In particular, the enhancement of static shunt via combined $\mathrm{K} / \mathrm{Cl} /$ cation leak channel support appears to be a promising strategy.

\section{Acknowledgments}

JW and DL were/are funded via the grants SFB780/C2 and WO1563/1-1 of the Deutsche Forschungsgemeinschaft (DFG), respectively.

after 4-aminopyridine-induced epilepsy. Eur. J. Neurosci. 22, 3067-3076. doi: 10.1111/j.1460-9568.2005.04509.x

Baek, J. H., Rubinstein, M., Scheuer, T., and Trimmer, J. S. (2014). Reciprocal changes in phosphorylation and methylation of mammalian brain sodium channels in response to seizures. J. Biol. Chem. 289, 15363-15373. doi: 10.1074/jbc.M114.562785

Barmashenko, G., Hefft, S., Aertsen, A., Kirschstein, T., and Köhling, R. (2011). Positive shifts of the $\operatorname{GABA}(\mathrm{A})$ receptor reversal potential due to altered chloride homeostasis is widespread after status epilepticus. Epilepsia 52, 1570-1578. doi: 10.1111/j.1528-1167.2011.03247.x

Bartolomei, F., Gastaldi, M., Massacrier, A., Planells, R., Nicolas, S., and Cau, P. (1997). Changes in the mRNAs encoding subtypes I, II and III sodium channel alpha subunits following kainate-induced seizures in rat brain. J. Neurocytol. 26, 667-678. doi: 10.1023/A:101854 9928277

Baruscotti, M., Bottelli, G., Milanesi, R., Difrancesco, J. C., and Difrancesco, D. (2010). HCN-related channelopathies. Pflugers Arch. 460, 405-415. doi: 10.1007/s00424-010-0810-8

Beck, H., Blumcke, I., Kral, T., Clusmann, H., Schramm, J., Wiestler, O. D., et al. (1996). Properties of a delayed rectifier potassium current in dentate granule cells isolated from the hippocampus of patients with chronic 
temporal lobe epilepsy. Epilepsia 37, 892-901. doi: 10.1111/j.1528-1157.1996. tb00043.x

Beck, H., Steffens, R., Elger, C. E., and Heinemann, U. (1998). Voltage-dependent $\mathrm{Ca}^{2+}$ currents in epilepsy. Epilepsy Res. 32, 321-332. doi: 10.1016/S09201211(98)00062-X

Beck, H., and Yaari, Y. (2008). Plasticity of intrinsic neuronal properties in CNS disorders. Nat. Rev. Neurosci. 9, 357-369. doi: 10.1038/nrn2371

Becker, A. J., Chen, J., Zien, A., Sochivko, D., Normann, S., Schramm, J., et al. (2003). Correlated stage- and subfield-associated hippocampal gene expression patterns in experimental and human temporal lobe epilepsy. Eur. J. Neurosci. 18, 2792-2802. doi: 10.1111/j.1460-9568.2003.02993.x

Becker, A. J., Pitsch, J., Sochivko, D., Opitz, T., Staniek, M., Chen, C. C., et al. (2008). Transcriptional upregulation of Cav3.2 mediates epileptogenesis in the pilocarpine model of epilepsy. J. Neurosci. 28, 13341-13353. doi: 10.1523/JNEUROSCI.1421-08.2008

Ben-Ari, Y. (1985). Limbic seizure and brain damage produced by kainic acid: mechanisms and relevance to human temporal lobe epilepsy. Neuroscience 14, 375-403. doi: 10.1016/0306-4522(85)90299-4

Ben-Ari, Y. (2008). Epilepsies and neuronal plasticity: for better or for worse? Dialogues Clin. Neurosci. 10, 17-27.

Bender, R. A., and Baram, T. Z. (2007). Epileptogenesis in the developing brain: what can we learn from animal models? Epilepsia 48(Suppl. 5), 2-6. doi: 10.1111/j.1528-1167.2007.01281.x

Bender, R. A., Soleymani, S. V., Brewster, A. L., Nguyen, S. T., Beck, H., Mathern, G. W., et al. (2003). Enhanced expression of a specific hyperpolarization-activated cyclic nucleotide-gated cation channel $(\mathrm{HCN})$ in surviving dentate gyrus granule cells of human and experimental epileptic hippocampus. J. Neurosci. 23, 6826-6836.

Berger, T., Larkum, M. E., and Luscher, H. R. (2001). High I(h) channel density in the distal apical dendrite of layer $\mathrm{V}$ pyramidal cells increases bidirectional attenuation of EPSPs. J. Neurophysiol. 85, 855-868.

Bernard, C., Anderson, A., Becker, A., Poolos, N. P., Beck, H., and Johnston, D. (2004). Acquired dendritic channelopathy in temporal lobe epilepsy. Science 305, 532-535. doi: 10.1126/science.1097065

Bertelli, M., Cecchin, S., Lapucci, C., De Gemmis, P., Danieli, D., D’Amore, E. S., et al. (2007). Quantification of chloride channel 2 (CLCN2) gene isoforms in normal versus lesion- and epilepsy-associated brain tissue. Biochim. Biophys. Acta 1772, 15-20. doi: 10.1016/j.bbadis.2006.10.015

Bertram, E. H., Mangan, P. S., Zhang, D., Scott, C. A., and Williamson, J. M. (2001). The midline thalamus: alterations and a potential role in limbic epilepsy. Epilepsia 42, 967-978. doi: 10.1046/j.1528-1157.2001.04200 8967.x

Biervert, C., Schroeder, B. C., Kubisch, C., Berkovic, S. F., Propping, P., Jentsch, T. J., et al. (1998). A potassium channel mutation in neonatal human epilepsy. Science 279, 403-406. doi: 10.1126/science.279.5349.403

Blair, R. E., Sombati, S., Churn, S. B., and Delorenzo, R. J. (2008). Epileptogenesis causes an $\mathrm{N}$-methyl-d-aspartate receptor/ $\mathrm{Ca}^{2+}$-dependent decrease in $\mathrm{Ca}^{2+} /$ calmodulin-dependent protein kinase II activity in a hippocampal neuronal culture model of spontaneous recurrent epileptiform discharges. Eur. J. Pharmacol. 588, 64-71. doi: 10.1016/j.ejphar.2008.04.021

Blümcke, I., Coras, R., Miyata, H., and Ozkara, C. (2012). Defining cliniconeuropathological subtypes of mesial temporal lobe epilepsy with hippocampal sclerosis. Brain Pathol. 22, 402-411. doi: 10.1111/j.1750-3639.2012. 00583.x

Blümcke, I., Thom, M., Aronica, E., Armstrong, D. D., Bartolomei, F., Bernasconi, A., et al. (2013). International consensus classification of hippocampal sclerosis in temporal lobe epilepsy: a Task Force report from the ILAE Commission on Diagnostic Methods. Epilepsia 54, 1315-1329. doi: 10.1111/epi.12220

Blümcke, I., Thom, M., and Wiestler, O. D. (2002). Ammon's horn sclerosis: a maldevelopmental disorder associated with temporal lobe epilepsy. Brain Pathol. 12, 199-211.

Blumenfeld, H., Lampert, A., Klein, J. P., Mission, J., Chen, M. C., Rivera, M., et al. (2009). Role of hippocampal sodium channel Nav1.6 in kindling epileptogenesis. Epilepsia 50, 44-55. doi: 10.1111/j.1528-1167.2008.01710.x

Blumenfeld, H., and Meador, K. J. (2014). Consciousness as a useful concept in epilepsy classification. Epilepsia 55, 1145-1150. doi: 10.1111/epi.12588

Boison, D. (2012). Adenosine dysfunction in epilepsy. Glia 60, 1234-1243. doi: 10.1002/glia.22285
Bordey, A., and Sontheimer, H. (1998). Properties of human glial cells associated with epileptic seizure foci. Epilepsy Res. 32, 286-303. doi: 10.1016/S09201211(98)00059-X

Bouilleret, V., Loup, F., Kiener, T., Marescaux, C., and Fritschy, J. M. (2000). Early loss of interneurons and delayed subunit-specific changes in GABA(A)-receptor expression in a mouse model of mesial temporal lobe epilepsy. Hippocampus 10, 305-324. doi: 10.1002/1098-1063(2000)10:3<305: AID-HIPO11>3.0.CO;2-I

Bouilleret, V., Ridoux, V., Depaulis, A., Marescaux, C., Nehlig, A., and Le Gal La Salle, G. (1999). Recurrent seizures and hippocampal sclerosis following intrahippocampal kainate injection in adult mice: electroencephalography, histopathology and synaptic reorganization similar to mesial temporal lobe epilepsy. Neuroscience 89, 717-729. doi: 10.1016/S0306-4522(98)00401-1

Brenner, R., Chen, Q. H., Vilaythong, A., Toney, G. M., Noebels, J. L., and Aldrich, R. W. (2005). BK channel beta4 subunit reduces dentate gyrus excitability and protects against temporal lobe seizures. Nat. Neurosci. 8, 1752-1759. doi: 10.1038/nn1573

Brewster, A., Bender, R. A., Chen, Y., Dube, C., Eghbal-Ahmadi, M., and Baram, T. Z. (2002). Developmental febrile seizures modulate hippocampal gene expression of hyperpolarization-activated channels in an isoform- and cellspecific manner. J. Neurosci. 22, 4591-4599.

Briellmann, R. S., Mark Wellard, R., Masterton, R. A., Abbott, D. F., Berkovic, S. F., and Jackson, G. D. (2007). Hippocampal sclerosis: MR prediction of seizure intractability. Epilepsia 48, 315-323. doi: 10.1111/j.1528-1167.2006. 00932.x

Brooks-Kayal, A. R., Shumate, M. D., Jin, H., Rikhter, T. Y., and Coulter, D. A. (1998). Selective changes in single cell $\mathrm{GABA}(\mathrm{A})$ receptor subunit expression and function in temporal lobe epilepsy. Nat. Med. 4, 1166-1172. doi: $10.1038 / 2661$

Budde, T., Caputi, L., Kanyshkova, T., Staak, R., Abrahamczik, C., Munsch, T., et al. (2005). Impaired regulation of thalamic pacemaker channels through an imbalance of subunit expression in absence epilepsy. J. Neurosci. 25, 9871-9882. doi: 10.1523/JNEUROSCI.2590-05.2005

Bumanglag, A. V., and Sloviter, R. S. (2008). Minimal latency to hippocampal epileptogenesis and clinical epilepsy after perforant pathway stimulationinduced status epilepticus in awake rats. J. Comp. Neurol. 510, 561-580. doi: 10.1002/cne.21801

Buono, R. J., Lohoff, F. W., Sander, T., Sperling, M. R., O’Connor, M. J., Dlugos, D. J., et al. (2004). Association between variation in the human $\mathrm{KCNJ} 10$ potassium ion channel gene and seizure susceptibility. Epilepsy Res. 58, 175-183. doi: 10.1016/j.eplepsyres.2004.02.003

Castro, P. A., Cooper, E. C., Lowenstein, D. H., and Baraban, S. C. (2001). Hippocampal heterotopia lack functional Kv4.2 potassium channels in the methylazoxymethanol model of cortical malformations and epilepsy. J. Neurosci. 21, 6626-6634.

Cavalleri, G. L., Weale, M. E., Shianna, K. V., Singh, R., Lynch, J. M., Grinton, B., et al. (2007). Multicentre search for genetic susceptibility loci in sporadic epilepsy syndrome and seizure types: a case-control study. Lancet Neurol. 6, 970-980. doi: 10.1016/S1474-4422(07)70247-8

Cestele, S., Scalmani, P., Rusconi, R., Terragni, B., Franceschetti, S., and Mantegazza, M. (2008). Self-limited hyperexcitability: functional effect of a familial hemiplegic migraine mutation of the Nav1.1 (SCN1A) $\mathrm{Na}^{+}$channel. J. Neurosci. 28, 7273-7283. doi: 10.1523/JNEUROSCI.4453-07.2008

Charlier, C., Singh, N. A., Ryan, S. G., Lewis, T. B., Reus, B. E., Leach, R. J., et al. (1998). A pore mutation in a novel KQT-like potassium channel gene in an idiopathic epilepsy family. Nat. Genet. 18, 53-55. doi: 10.1038/ng098-53

Chen, C., Bharucha, V., Chen, Y., Westenbroek, R. E., Brown, A., Malhotra, J. D., et al. (2002). Reduced sodium channel density, altered voltage dependence of inactivation, and increased susceptibility to seizures in mice lacking sodium channel beta 2-subunits. Proc. Natl. Acad. Sci. U.S.A. 99, 17072-17077. doi: $10.1073 /$ pnas. 212638099

Chen, K., Aradi, I., Thon, N., Eghbal-Ahmadi, M., Baram, T. Z., and Soltesz, I. (2001). Persistently modified h-channels after complex febrile seizures convert the seizure-induced enhancement of inhibition to hyperexcitability. Nat. Med. 7, 331-337. doi: 10.1038/85480

Chen, Y., Kundakovic, M., Agis-Balboa, R. C., Pinna, G., and Grayson, D. R. (2007). Induction of the reelin promoter by retinoic acid is mediated by Sp1. J. Neurochem. 103, 650-665. doi: 10.1111/j.1471-4159.2007.04797.x 
Chioza, B., Osei-Lah, A., Wilkie, H., Nashef, L., McCormick, D., Asherson, P., et al. (2002). Suggestive evidence for association of two potassium channel genes with different idiopathic generalised epilepsy syndromes. Epilepsy Res. 52, 107-116. doi: 10.1016/S0920-1211(02)00195-X

Choi, D. W. (1992). Excitotoxic cell death. J. Neurobiol. 23, 1261-1276. doi: 10.1002/neu.480230915

Chung, H. J., Jan, Y. N., and Jan, L. Y. (2006). Polarized axonal surface expression of neuronal KCNQ channels is mediated by multiple signals in the KCNQ2 and KCNQ3 C-terminal domains. Proc. Natl. Acad. Sci. U.S.A. 103, 8870-8875. doi: 10.1073/pnas.0603376103

Cobb, S. R., Buhl, E. H., Halasy, K., Paulsen, O., and Somogyi, P. (1995). Synchronization of neuronal activity in hippocampus by individual GABAergic interneurons. Nature 378, 75-78. doi: 10.1038/378075a0

Coetzee, W. A., Amarillo, Y., Chiu, J., Chow, A., Lau, D., Mccormack, T., et al. (1999). Molecular diversity of K+ channels. Ann. N.Y. Acad. Sci. 868, 233-285. doi: 10.1111/j.1749-6632.1999.tb11293.x

Cohen, I., Navarro, V., Clemenceau, S., Baulac, M., and Miles, R. (2002). On the origin of interictal activity in human temporal lobe epilepsy in vitro. Science 298, 1418-1421. doi: 10.1126/science.1076510

Coleman, N., Nguyen, H. M., Cao, Z., Brown, B. M., Jenkins, D. P., Zolkowska, D., et al. (2015). The riluzole derivative 2-amino-6-trifluoromethylthiobenzothiazole (SKA-19), a mixed K2 Activator and na blocker, is a potent novel anticonvulsant. Neurotherapeutics 12, 234-249. doi: 10.1007/s13311-0140305-y

Cope, D. W., Di Giovanni, G., Fyson, S. J., Orban, G., Errington, A. C., Lorincz, M. L., et al. (2009). Enhanced tonic GABAA inhibition in typical absence epilepsy. Nat. Med. 15, 1392-1398. doi: 10.1038/nm.2058

Coulson, E. J., May, L. M., Osborne, S. L., Reid, K., Underwood, C. K., Meunier, F. A., et al. (2008). p75 neurotrophin receptor mediates neuronal cell death by activating GIRK channels through phosphatidylinositol 4,5-bisphosphate. J. Neurosci. 28, 315-324. doi: 10.1523/JNEUROSCI.2699-07.2008

Coulter, D. A. (2000). Mossy fiber zinc and temporal lobe epilepsy: pathological association with altered "epileptic" gamma-aminobutyric acid A receptors in dentate granule cells. Epilepsia 41(Suppl. 6), S96-S99. doi: 10.1111/j.15281157.2000.tb01565.x

Coulter, D. A., Mcintyre, D. C., and Löscher, W. (2002). Animal models of limbic epilepsies: what can they tell us? Brain Pathol. 12, 240-256. doi: 10.1111/j.17503639.2002.tb00439.x

Crunelli, V., and Leresche, N. (2002). Block of thalamic T-Type Ca(2+) channels by ethosuximide is not the whole story. Epilepsy Curr. 2, 53-56. doi: 10.1046/j.1535-7597.2002.00024.x

Curia, G., Lucchi, C., Vinet, J., Gualtieri, F., Marinelli, C., Torsello, A., et al. (2014). Pathophysiogenesis of mesial temporal lobe epilepsy: is prevention of damage antiepileptogenic? Curr. Med. Chem. 21, 663-688. doi: 10.2174/0929867320666131119152201

D’adamo, M. C., Catacuzzeno, L., Di Giovanni, G., Franciolini, F., and Pessia, M. (2013). $\mathrm{K}(+)$ channelepsy: progress in the neurobiology of potassium channels and epilepsy. Front. Cell. Neurosci. 7:134. doi: 10.3389/fncel.2013.00134

D’antuono, M., Louvel, J., Köhling, R., Mattia, D., Bernasconi, A., Olivier, A., et al. (2004). GABAA receptor-dependent synchronization leads to ictogenesis in the human dysplastic cortex. Brain 127, 1626-1640. doi: 10.1093/brain/awh181

Danielsson, B. R., Lansdell, K., Patmore, L., and Tomson, T. (2003). Phenytoin and phenobarbital inhibit human HERG potassium channels. Epilepsy Res. 55, 147-157. doi: 10.1016/S0920-1211(03)00119-0

Danielsson, B. R., Lansdell, K., Patmore, L., and Tomson, T. (2005). Effects of the antiepileptic drugs lamotrigine, topiramate and gabapentin on hERG potassium currents. Epilepsy Res. 63, 17-25. doi: 10.1016/j.eplepsyres.2004.10.002

Davis, G. W., and Bezprozvanny, I. (2001). Maintaining the stability of neural function: a homeostatic hypothesis. Annu. Rev. Physiol. 63, 847-869. doi: 10.1146/annurev.physiol.63.1.847

De Kovel, C. G., Meisler, M. H., Brilstra, E. H., Van Berkestijn, F. M., Van 'T Slot, R., Van Lieshout, S., et al. (2014). Characterization of a de novo SCN8A mutation in a patient with epileptic encephalopathy. Epilepsy Res. 108, 1511-1518. doi: 10.1016/j.eplepsyres.2014.08.020

De Lanerolle, N. C., Brines, M., Williamson, A., Kim, J. H., and Spencer, D. D. (1992). Neurotransmitters and their receptors in human temporal lobe epilepsy. Epilepsy Res. Suppl. 7, 235-250.
De Lanerolle, N. C., Kim, J. H., Williamson, A., Spencer, S. S., Zaveri, H. P., Eid T., et al. (2003). A retrospective analysis of hippocampal pathology in human temporal lobe epilepsy: evidence for distinctive patient subcategories. Epilepsia 44, 677-687. doi: 10.1046/j.1528-1157.2003.32701.x

De Lanerolle, N. C., and Lee, T. S. (2005). New facets of the neuropathology and molecular profile of human temporal lobe epilepsy. Epilepsy Behav. 7, 190-203. doi: 10.1016/j.yebeh.2005.06.003

De Tisi, J., Bell, G. S., Peacock, J. L., Mcevoy, A. W., Harkness, W. F., Sander, J. W., et al. (2011). The long-term outcome of adult epilepsy surgery, patterns of seizure remission, and relapse: a cohort study. Lancet 378, 1388-1395. doi: 10.1016/S0140-6736(11)60890-8

Delorenzo, R. J., Sun, D. A., and Deshpande, L. S. (2005). Cellular mechanisms underlying acquired epilepsy: the calcium hypothesis of the induction and maintainance of epilepsy. Pharmacol. Ther. 105, 229-266. doi: 10.1016/j.pharmthera.2004.10.004

Depaulis, A., Vergnes, M., and Marescaux, C. (1994). Endogenous control of epilepsy: the nigral inhibitory system. Prog. Neurobiol. 42, 33-52. doi: 10.1016/0301-0082(94)90020-5

Desai, N. S., Rutherford, L. C., and Turrigiano, G. G. (1999). Plasticity in the intrinsic excitability of cortical pyramidal neurons. Nat. Neurosci. 2, 515-520. doi: $10.1038 / 9165$

Dey, D., Eckle, V. S., Vitko, I., Sullivan, K. A., Lasiecka, Z. M., Winckler, B., et al. (2014). A potassium leak channel silences hyperactive neurons and ameliorates status epilepticus. Epilepsia 55, 203-213. doi: 10.1111/epi.12472

Dietrich, D., Clusmann, H., Kral, T., Steinhauser, C., Blumcke, I., Heinemann, U., et al. (1999). Two electrophysiologically distinct types of granule cells in epileptic human hippocampus. Neuroscience 90, 1197-1206. doi: 10.1016/S0306-4522(98)00574-0

Dietrich, D., Podlogar, M., Ortmanns, G., Clusmann, H., and Kral, T. (2005) Calbindin-D28k content and firing pattern of hippocampal granule cells in amygdala-kindled rats: a perforated patch-clamp study. Brain Res. 1032, 123-130. doi: 10.1016/j.brainres.2004.10.060

Djamshidian, A., Grassl, R., Seltenhammer, M., Czech, T., Baumgartner, C., Schmidbauer, M., et al. (2002). Altered expression of voltage-dependent calcium channel alpha(1) subunits in temporal lobe epilepsy with Ammon's horn sclerosis. Neuroscience 111, 57-69. doi: 10.1016/S0306-4522(01)00528-0

Dost, R., Rostock, A., and Rundfeldt, C. (2004). The anti-hyperalgesic activity of retigabine is mediated by KCNQ potassium channel activation. Naunyn Schmiedebergs. Arch. Pharmacol. 369, 382-390. doi: 10.1007/s00210-0040881-1

Du, W., Bautista, J. F., Yang, H., Diez-Sampedro, A., You, S. A., Wang, L., et al. (2005). Calcium-sensitive potassium channelopathy in human epilepsy and paroxysmal movement disorder. Nat. Genet. 37, 733-738. doi: 10.1038/ng1585

Dugladze, T., Vida, I., Tort, A. B., Gross, A., Otahal, J., Heinemann, U., et al. (2007). Impaired hippocampal rhythmogenesis in a mouse model of mesial temporal lobe epilepsy. Proc. Natl. Acad. Sci. U.S.A. 104, 17530-17535. doi: 10.1073/pnas.0708301104

Dyhrfjeld-Johnsen, J., Morgan, R. J., Foldy, C., and Soltesz, I. (2008). Upregulated H-Current in Hyperexcitable CA1 Dendrites after Febrile Seizures. Front. Cell. Neurosci. 2:2. doi: 10.3389/neuro.03.002.2008

Dyhrfjeld-Johnsen, J., Morgan, R. J., and Soltesz, I. (2009). Double trouble? potential for hyperexcitability following both channelopathic up- and downregulation of $\mathrm{I}(\mathrm{h})$ in epilepsy. Front. Neurosci. 3, 25-33. doi: 10.3389/neuro.01.005.2009

Eichler, S. A., Kirischuk, S., Juttner, R., Schaefermeier, P. K., Legendre, P., Lehmann, T. N., et al. (2008). Glycinergic tonic inhibition of hippocampal neurons with depolarizing GABAergic transmission elicits histopathological signs of temporal lobe epilepsy. J. Cell. Mol. Med. 12, 2848-2866. doi: 10.1111/j.1582-4934.2008.00357.x

Elliott, R. C., Miles, M. F., and Lowenstein, D. H. (2003). Overlapping microarray profiles of dentate gyrus gene expression during developmentand epilepsy-associated neurogenesis and axon outgrowth. J. Neurosci. 23, 2218-2227.

Fan, Y., Fricker, D., Brager, D. H., Chen, X., Lu, H. C., Chitwood, R. A., et al. (2005) Activity-dependent decrease of excitability in rat hippocampal neurons through increases in I(h). Nat. Neurosci. 8, 1542-1551. doi: 10.1038/nn1568

Faulkner, M. A., and Burke, R. A. (2013). Safety profile of two novel antiepileptic agents approved for the treatment of refractory partial seizures: ezogabine 
(retigabine) and perampanel. Expert Opin. Drug Saf. 12, 847-855. doi: 10.1517/14740338.2013.823399

Feng, Z., Chang, R. C., Bing, G., Hudson, P., Tiao, N., Jin, L., et al. (1999). Longterm increase of Sp-1 transcription factors in the hippocampus after kainic acid treatment. Brain Res. Mol. Brain Res. 69, 144-148. doi: 10.1016/S0169328X(99)00099-6

Francis, J., Jugloff, D. G., Mingo, N. S., Wallace, M. C., Jones, O. T., Burnham, W. M., et al. (1997). Kainic acid-induced generalized seizures alter the regional hippocampal expression of the rat Kv4.2 potassium channel gene. Neurosci. Lett. 232, 91-94. doi: 10.1016/S0304-3940(97)00593-4

Fritschy, J. M. (2004). A new animal model of temporal lobe epilepsy. Epileptologie, 21-28.

Gandolfo, G., Gottesmann, C., Bidard, J. N., and Lazdunski, M. (1989a). K+ channels openers prevent epilepsy induced by the bee venom peptide MCD. Eur. J. Pharmacol. 159, 329-330.

Gandolfo, G., Romettino, S., Gottesmann, C., Van Luijtelaar, G., Coenen, A., Bidard, J. N., et al. (1989b). K+ channel openers decrease seizures in genetically epileptic rats. Eur. J. Pharmacol. 167, 181-183.

Gasparini, S., and Difrancesco, D. (1997). Action of the hyperpolarizationactivated current (Ih) blocker ZD 7288 in hippocampal CA1 neurons. Pflugers Arch. 435, 99-106. doi: 10.1007/s004240050488

Gavrilovici, C., Pollock, E., Everest, M., and Poulter, M. O. (2012). The loss of interneuron functional diversity in the piriform cortex after induction of experimental epilepsy. Neurobiol. Dis. 48, 317-328. doi: 10.1016/j.nbd.2012.07.002

Ge, Y. X., Liu, Y., Tang, H. Y., Liu, X. G., and Wang, X. (2011). ClC-2 contributes to tonic inhibition mediated by alpha5 subunit-containing GABA(A) receptor in experimental temporal lobe epilepsy. Neuroscience 186, 120-127. doi: 10.1016/j.neuroscience.2011.04.029

George, A. L. Jr. (2004). Inherited channelopathies associated with epilepsy. Epilepsy Curr. 4, 65-70. doi: 10.1111/j.1535-7597.2004.42010.x

Gibbs, J. W. III., Shumate, M. D., and Coulter, D. A. (1997). Differential epilepsyassociated alterations in postsynaptic $\mathrm{GABA}(\mathrm{A})$ receptor function in dentate granule and CA1 neurons. J. Neurophysiol. 77, 1924-1938.

Glykys, J., Mann, E. O., and Mody, I. (2008). Which GABA(A) receptor subunits are necessary for tonic inhibition in the hippocampus? J. Neurosci. 28, 1421-1426. doi: 10.1523/JNEUROSCI.4751-07.2008

Goddard, G. V., Mcintyre, D. C., and Leech, C. K. (1969). A permanent change in brain function resulting from daily electrical stimulation. Exp. Neurol. 25, 295-330. doi: 10.1016/0014-4886(69)90128-9

Goldstein, S. A., Bayliss, D. A., Kim, D., Lesage, F., Plant, L. D., and Rajan, S. (2005). International union of pharmacology. LV. Nomenclature and molecular relationships of two-P potassium channels. Pharmacol. Rev. 57, 527-540. doi: $10.1124 /$ pr.57.4.12

Golowasch, J., Abbott, L. F., and Marder, E. (1999). Activity-dependent regulation of potassium currents in an identified neuron of the stomatogastric ganglion of the crab Cancer borealis. J. Neurosci. 19:RC33.

Goodkin, H. P., Joshi, S., Mtchedlishvili, Z., Brar, J., and Kapur, J. (2008). Subunitspecific trafficking of GABA(A) receptors during status epilepticus. J. Neurosci. 28, 2527-2538. doi: 10.1523/JNEUROSCI.3426-07.2008

Gower, W. R. (1881). Epilepsy and Other Chronic Convulsive Disorders, their Causes, Symptoms and Treatment. London: J \& A Churchill.

Graef, J. D., Nordskog, B. K., Wiggins, W. F., and Godwin, D. W. (2009). An acquired channelopathy involving thalamic T-type Ca2+ channels after status epilepticus. J. Neurosci. 29, 4430-4441. doi: 10.1523/JNEUROSCI.019809.2009

Grunze, H., Von Wegerer, J., Greene, R. W., and Walden, J. (1998). Modulation of calcium and potassium currents by lamotrigine. Neuropsychobiology 38, 131-138. doi: 10.1159/000026528

Gutman, G. A., Chandy, K. G., Grissmer, S., Lazdunski, M., McKinnon, D., Pardo, L. A., et al. (2005). International Union of Pharmacology. LIII. Nomenclature and molecular relationships of voltage-gated potassium channels. Pharmacol. Rev. 57, 473-508. doi: 10.1124/pr.57.4.10

Haas, C. A., Dudeck, O., Kirsch, M., Huszka, C., Kann, G., Pollak, S., et al. (2002). Role for reelin in the development of granule cell dispersion in temporal lobe epilepsy. J. Neurosci. 22, 5797-5802.

Hargus, N. J., Nigam, A., Bertram, E. H. III, and Patel, M. K. (2013). Evidence for a role of Nav1.6 in facilitating increases in neuronal hyperexcitability during epileptogenesis. J. Neurophysiol. 110, 1144-1157. doi: 10.1152/jn.003 83.2013

Harvey, B. D., and Sloviter, R. S. (2005). Hippocampal granule cell activity and c-Fos expression during spontaneous seizures in awake, chronically epileptic, pilocarpine-treated rats: implications for hippocampal epileptogenesis. J. Comp. Neurol. 488, 442-463. doi: 10.1002/cne.20594

Hauser, W. A., and Lee, J. R. (2002). Do seizures beget seizures? Prog. Brain Res. $135,215-219$.

Häussler, U., Bielefeld, L., Froriep, U. P., Wolfart, J., and Haas, C. A. (2012). Septotemporal position in the hippocampal formation determines epileptic and neurogenic activity in temporal lobe epilepsy. Cereb. Cortex 22, 26-36. doi: 10.1093/cercor/bhr054

He, Y., Zorumski, C. F., and Mennerick, S. (2002). Contribution of presynaptic $\mathrm{Na}(+)$ channel inactivation to paired-pulse synaptic depression in cultured hippocampal neurons. J. Neurophysiol. 87, 925-936.

Hedrich, U. B., Liautard, C., Kirschenbaum, D., Pofahl, M., Lavigne, J., Liu, Y., et al. (2014). Impaired Action Potential Initiation in GABAergic Interneurons Causes Hyperexcitable Networks in an Epileptic Mouse Model Carrying a Human NaV1.1 Mutation. J. Neurosci. 34, 14874-14889. doi: 10.1523/JNEUROSCI.0721-14.2014

Heilstedt, H. A., Burgess, D. L., Anderson, A. E., Chedrawi, A., Tharp, B., Lee, O., et al. (2001). Loss of the potassium channel beta-subunit gene, KCNAB2, is associated with epilepsy in patients with 1 p36 deletion syndrome. Epilepsia 42, 1103-1111. doi: 10.1046/j.1528-1157.2001.08801.x

Heinemann, U., Beck, H., Dreier, J. P., Ficker, E., Stabel, J., and Zhang, C. L. (1992). The dentate gyrus as a regulated gate for the propagation of epileptiform activity. Epilepsy Res. Suppl. 7, 273-280.

Heuser, K., Eid, T., Lauritzen, F., Thoren, A. E., Vindedal, G. F., Tauboll, E., et al. (2012). Loss of perivascular Kir4.1 potassium channels in the sclerotic hippocampus of patients with mesial temporal lobe epilepsy. J. Neuropathol. Exp. Neurol. 71, 814-825. doi: 10.1097/NEN.0b013e318267b5af

Hinterkeuser, S., Schroder, W., Hager, G., Seifert, G., Blumcke, I., Elger, C. E., et al. (2000). Astrocytes in the hippocampus of patients with temporal lobe epilepsy display changes in potassium conductances. Eur. J. Neurosci. 12, 2087-2096. doi: 10.1046/j.1460-9568.2000.00104.x

Hoffman, E. P. (1995). Voltage-gated ion channelopathies: inherited disorders caused by abnormal sodium, chloride, and calcium regulation in skeletal muscle. Annu. Rev. Med. 46, 431-441. doi: 10.1146/annurev.med.46.1.431

Houser, C. R. (1990). Granule cell dispersion in the dentate gyrus of humans with temporal lobe epilepsy. Brain Res. 535, 195-204. doi: 10.1016/00068993(90)91601-C

Hsu, D. (2007). The dentate gyrus as a filter or gate: a look back and a look ahead. Prog. Brain Res. 163, 601-613. doi: 10.1016/S0079-6123(07)63032-5

Hu, H. J., Carrasquillo, Y., Karim, F., Jung, W. E., Nerbonne, J. M., Schwarz, T. L., et al. (2006). The kv4.2 potassium channel subunit is required for pain plasticity. Neuron 50, 89-100. doi: 10.1016/j.neuron.2006.03.010

Huang, C. W., Huang, C. C., Liu, Y. C., and Wu, S. N. (2004). Inhibitory effect of lamotrigine on A-type potassium current in hippocampal neuronderived H19-7 cells. Epilepsia 45, 729-736. doi: 10.1111/j.0013-9580.2004. 58403.x

Huang, C. W., Huang, C. C., and Wu, S. N. (2006). The opening effect of pregabalin on ATP-sensitive potassium channels in differentiated hippocampal neuron-derived H19-7 cells. Epilepsia 47, 720-726. doi: 10.1111/j.15281167.2006.00498.x

Huang, C. W., Huang, C. C., and Wu, S. N. (2007). Activation by zonisamide, a newer antiepileptic drug, of large-conductance calcium-activated potassium channel in differentiated hippocampal neuron-derived H19-7 cells. J. Pharmacol. Exp. Ther. 321, 98-106. doi: 10.1124/jpet.106.116954

Huang, Z., Walker, M. C., and Shah, M. M. (2009). Loss of dendritic HCN1 subunits enhances cortical excitability and epileptogenesis. J. Neurosci. 29, 10979-10988. doi: 10.1523/JNEUROSCI.1531-09.2009

Huberfeld, G., Wittner, L., Clemenceau, S., Baulac, M., Kaila, K., Miles, R., et al. (2007). Perturbed chloride homeostasis and GABAergic signaling in human temporal lobe epilepsy. J. Neurosci. 27, 9866-9873. doi: 10.1523/JNEUROSCI.2761-07.2007

Hyun, J. H., Eom, K., Lee, K. H., Ho, W. K., and Lee, S. H. (2013). Activitydependent downregulation of D-type $\mathrm{K}+$ channel subunit Kv1.2 in rat hippocampal CA3 pyramidal neurons. J. Physiol. (Lond). 
Ishii, A., Fukuma, G., Uehara, A., Miyajima, T., Makita, Y., Hamachi, A., et al. (2009). A de novo KCNQ2 mutation detected in non-familial benign neonatal convulsions. Brain Dev. 31, 27-33. doi: 10.1016/j.braindev.2008.05.010

Isokawa, M. (1996). Decrement of GABAA receptor-mediated inhibitory postsynaptic currents in dentate granule cells in epileptic hippocampus. J. Neurophysiol. 75, 1901-1908.

Isokawa, M., and Levesque, M. F. (1991). Increased NMDA responses and dendritic degeneration in human epileptic hippocampal neurons in slices. Neurosci. Lett. 132, 212-216. doi: 10.1016/0304-3940(91)90304-C

Isokawa, M., and Mello, L. E. (1991). NMDA receptor-mediated excitability in dendritically deformed dentate granule cells in pilocarpine-treated rats. Neurosci. Lett. 129, 69-73. doi: 10.1016/0304-3940(91)90722-6

Jabs, R., Seifert, G., and Steinhauser, C. (2008). Astrocytic function and its alteration in the epileptic brain. Epilepsia 49(Suppl. 2), 3-12. doi: 10.1111/j.1528-1167.2008.01488.x

Jefferys, J. G. (1999). Hippocampal sclerosis and temporal lobe epilepsy: cause or consequence? Brain 122(Pt 6), 1007-1008.

Jensen, F. E., and Baram, T. Z. (2000). Developmental seizures induced by common early-life insults: short- and long-term effects on seizure susceptibility. Ment. Retard. Dev. Disabil. Res. Rev. 6, 253-257. doi: 10.1002/10982779(2000)6:4<253::AID-MRDD4>3.0.CO;2-P

Jensen, H. S., Grunnet, M., and Bastlund, J. F. (2014). Therapeutic potential of $\mathrm{Na}(\mathrm{V}) 1.1$ activators. Trends Pharmacol. Sci. 35, 113-118. doi: 10.1016/j.tips.2013.12.007

Jin, W., Sugaya, A., Tsuda, T., Ohguchi, H., and Sugaya, E. (2000). Relationship between large conductance calcium-activated potassium channel and bursting activity. Brain Res. 860, 21-28. doi: 10.1016/S0006-8993(00) 01943-0

Jobst, B. C., and Cascino, G. D. (2015). Resective epilepsy surgery for drug-resistant focal epilepsy: a review. JAMA 313, 285-293. doi: 10.1001/jama.2014.17426

Jung, S., Bullis, J. B., Lau, I. H., Jones, T. D., Warner, L. N., and Poolos, N. P. (2010). Downregulation of dendritic HCN channel gating in epilepsy is mediated by altered phosphorylation signaling. J. Neurosci. 30, 6678-6688. doi: 10.1523/JNEUROSCI.1290-10.2010

Jung, S., Jones, T. D., Lugo, J. N. Jr., Sheerin, A. H., Miller, J. W., D’ambrosio, R., et al. (2007). Progressive dendritic HCN channelopathy during epileptogenesis in the rat pilocarpine model of epilepsy. J. Neurosci. 27, 13012-13021. doi: 10.1523/JNEUROSCI.3605-07.2007

Jung, S., Warner, L. N., Pitsch, J., Becker, A. J., and Poolos, N. P. (2011). Rapid loss of dendritic HCN channel expression in hippocampal pyramidal neurons following status epilepticus. J. Neurosci. 31, 14291-14295. doi: 10.1523/JNEUROSCI.1148-11.2011

Kanyshkova, T., Meuth, P., Bista, P., Liu, Z., Ehling, P., Caputi, L., et al. (2012). Differential regulation of $\mathrm{HCN}$ channel isoform expression in thalamic neurons of epileptic and non-epileptic rat strains. Neurobiol. Dis. 45, 450-461. doi: 10.1016/j.nbd.2011.08.032

Kasteleijn-Nolst Trenite, D. G., Biton, V., French, J. A., Abou-Khalil, B., Rosenfeld, W. E., Diventura, B., et al. (2013). Kv7 potassium channel activation with ICA105665 reduces photoparoxysmal EEG responses in patients with epilepsy. Epilepsia 54, 1437-1443. doi: 10.1111/epi.12224

Kaufmann, K., Romaine, I., Days, E., Pascual, C., Malik, A., Yang, L., et al. (2013). ML297 (VU0456810), the first potent and selective activator of the GIRK potassium channel, displays antiepileptic properties in mice. ACS Chem. Neurosci. 4, 1278-1286. doi: 10.1021/cn400062a

Ketelaars, S. O., Gorter, J. A., van Vliet, E. A., Lopes da Silva, F. H., and Wadman, W. J. (2001). Sodium currents in isolated rat CA1 pyramidal and dentate granule neurones in the post-status epilepticus model of epilepsy. Neuroscience 105, 109-120. doi: 10.1016/S0306-4522(01)00176-2

Khirug, S., Ahmad, F., Puskarjov, M., Afzalov, R., Kaila, K., and Blaesse, P. (2010). A Single Seizure episode leads to rapid functional activation of KCC2 in the neonatal rat hippocampus. J. Neurosci. 30, 12028-12035. doi: 10.1523/JNEUROSCI.3154-10.2010

Kienzler, F., Norwood, B. A., and Sloviter, R. S. (2009). Hippocampal injury, atrophy, synaptic reorganization, and epileptogenesis after perforant pathway stimulation-induced status epilepticus in the mouse. J. Comp. Neurol. 515, 181-196. doi: 10.1002/cne.22059

Kim, D. S., Kim, J. E., Kwak, S. E., Choi, H. C., Song, H. K., Kimg, Y. I., et al. (2007a). Up-regulated astroglial TWIK-related acid-sensitive K+ channel-1
(TASK-1) in the hippocampus of seizure-sensitive gerbils: a target of antiepileptic drugs. Brain Res. 1185, 346-358. doi: 10.1016/j.brainres.2007.09.043

Kim, D. S., Ryu, H. J., Kim, J. E., and Kang, T. C. (2013). The reverse roles of transient receptor potential canonical channel-3 and -6 in neuronal death following pilocarpine-induced status epilepticus. Cell. Mol. Neurobiol. 33, 99-109. doi: 10.1007/s10571-012-9875-6

Kim, J., Jung, S. C., Clemens, A. M., Petralia, R. S., and Hoffman, D. A. (2007b). Regulation of dendritic excitability by activity-dependent trafficking of the A-type K+ channel subunit Kv4.2 in hippocampal neurons. Neuron 54, 933-947. doi: 10.1016/j.neuron.2007.05.026

Kim, J. E., Kwak, S. E., Choi, H. C., Song, H. K., Kim, Y. I., Jo, S. M., et al. (2008a). Voltage-gated $\mathrm{Na}+$ channel II immunoreactivity is selectively up-regulated in hippocampal interneurons of seizure sensitive gerbils. Neurosci. Lett. 438, 295-299. doi: 10.1016/j.neulet.2008.04.079

Kim, J. E., Kwak, S. E., Choi, S. Y., and Kang, T. C. (2008b). Regionspecific alterations in astroglial TWIK-related acid-sensitive $\mathrm{K}+-1$ channel immunoreactivity in the rat hippocampal complex following pilocarpine-induced status epilepticus. J. Comp. Neurol. 510, 463-474. doi: $10.1002 /$ cne. 21767

Kim, J. E., Kwak, S. E., and Kang, T. C. (2009). Upregulated TWIK-related acid-sensitive $\mathrm{K}+$ channel- 2 in neurons and perivascular astrocytes in the hippocampus of experimental temporal lobe epilepsy. Epilepsia 50, 654-663. doi: 10.1111/j.1528-1167.2008.01957.x

Kim, K. S., Kobayashi, M., Takamatsu, K., and Tzingounis, A. V. (2012). Hippocalcin and KCNQ channels contribute to the kinetics of the slow afterhyperpolarization. Biophys. J. 103, 2446-2454. doi: 10.1016/j.bpj.2012.11.002

King, D., Bronen, R. A., Spencer, D. D., and Spencer, S. S. (1997). Topographic distribution of seizure onset and hippocampal atrophy: relationship between MRI and depth EEG. Electroencephalogr. Clin. Neurophysiol. 103, 692-697. doi: 10.1016/S0013-4694(97)00090-4

Kirchheim, F., Tinnes, S., Haas, C. A., Stegen, M., and Wolfart, J. (2013). Regulation of action potential delays via voltage-gated potassium Kv1.1 channels in dentate granule cells during hippocampal epilepsy. Front. Cell. Neurosci. 7:248. doi: 10.3389/fncel.2013.00248

Knuesel, I., Zuellig, R. A., Schaub, M. C., and Fritschy, J. M. (2001). Alterations in dystrophin and utrophin expression parallel the reorganization of GABAergic synapses in a mouse model of temporal lobe epilepsy. Eur. J. Neurosci. 13, 1113-1124. doi: 10.1046/j.0953-816x.2001.01476.x

Kobayashi, M., Wen, X., and Buckmaster, P. S. (2003). Reduced inhibition and increased output of layer II neurons in the medial entorhinal cortex in a model of temporal lobe epilepsy. J. Neurosci. 23, 8471-8479.

Kole, M. H., Brauer, A. U., and Stuart, G. J. (2007). Inherited cortical HCN1 channel loss amplifies dendritic calcium electrogenesis and burst firing in a rat absence epilepsy model. J. Physiol. 578, 507-525. doi: 10.1113/jphysiol.2006.122028

Kowalski, J., Geuting, M., Paul, S., Dieni, S., Laurens, J., Zhao, S., et al. (2010). Proper layering is important for precisely timed activation of hippocampal mossy cells. Cereb. Cortex 20, 2043-2054. doi: 10.1093/cercor/bhp267

Krook-Magnuson, E., Armstrong, C., Bui, A., Lew, S., Oijala, M., and Soltesz, I. (2015). In vivo evaluation of the dentate gate theory in epilepsy. J. Physiol. doi: $10.1113 / \mathrm{JP} 270056$

Kubo, Y., Adelman, J. P., Clapham, D. E., Jan, L. Y., Karschin, A., Kurachi, Y., et al. (2005). International Union of Pharmacology. LIV. Nomenclature and molecular relationships of inwardly rectifying potassium channels. Pharmacol. Rev. 57, 509-526. doi: 10.1124/pr.57.4.11

Kullmann, D. M., and Waxman, S. G. (2010). Neurological channelopathies: new insights into disease mechanisms and ion channel function. J. Physiol. 588, 1823-1827. doi: 10.1113/jphysiol.2010.190652

Kumar, S. S., and Buckmaster, P. S. (2006). Hyperexcitability, interneurons, and loss of GABAergic synapses in entorhinal cortex in a model of temporal lobe epilepsy. J. Neurosci. 26, 4613-4623. doi: 10.1523/JNEUROSCI.0064-06.2006

Lachance-Touchette, P., Brown, P., Meloche, C., Kinirons, P., Lapointe, L., Lacasse, H., et al. (2011). Novel alpha1 and gamma2 GABAA receptor subunit mutations in families with idiopathic generalized epilepsy. Eur. J. Neurosci. 34, 237-249. doi: 10.1111/j.1460-9568.2011.07767.x

Lau, D., Vega-Saenz De Miera, E. C., Contreras, D., Ozaita, A., Harvey, M., Chow, A., et al. (2000). Impaired fast-spiking, suppressed cortical inhibition, and 
increased susceptibility to seizures in mice lacking Kv3.2 $\mathrm{K}+$ channel proteins. J. Neurosci. 20, 9071-9085.

Le Duigou, C., Bouilleret, V., and Miles, R. (2008). Epileptiform activities in slices of hippocampus from mice after intra-hippocampal injection of kainic acid. J. Physiol. 586, 4891-4904. doi: 10.1113/jphysiol.2008.156281

Lee, C. H., and Liou, H. H. (2014). Pregabalin activates ROMK1 channels via cAMP-dependent protein kinase and protein kinase C. Eur. J. Pharmacol. 740, 35-44. doi: 10.1016/j.ejphar.2014.06.049

Lee, S. M., Kim, J. E., Sohn, J. H., Choi, H. C., Lee, J. S., Kim, S. H., et al. (2009). Down-regulation of delayed rectifier $\mathrm{K}+$ channels in the hippocampus of seizure sensitive gerbils. Brain Res. Bull. 80, 433-442. doi: 10.1016/j.brainresbull.2009.07.016

Levitan, I. B. (1994). Modulation of ion channels by protein phosphorylation and dephosphorylation. Annu. Rev. Physiol. 56, 193-212. doi: 10.1146/annurev.ph.56.030194.001205

Li, K. X., Lu, Y. M., Xu, Z. H., Zhang, J., Zhu, J. M., Zhang, J. M., et al. (2012). Neuregulin 1 regulates excitability of fast-spiking neurons through Kv1.1 and acts in epilepsy. Nat. Neurosci. 15, 267-273. doi: 10.1038/nn.3006

Limbrick, D. D. Jr., Sombati, S., and Delorenzo, R. J. (2003). Calcium influx constitutes the ionic basis for the maintenance of glutamate-induced extended neuronal depolarization associated with hippocampal neuronal death. Cell Calcium 33, 69-81. doi: 10.1016/S0143-4160(02)00054-4

Liu, M., Pleasure, S. J., Collins, A. E., Noebels, J. L., Naya, F. J., Tsai, M. J., et al. (2000). Loss of BETA2/NeuroD leads to malformation of the dentate gyrus and epilepsy. Proc. Natl. Acad. Sci. U.S.A. 97, 865-870. doi: 10.1073/pnas.97. 2.865

Liu, Y., Liu, D., Printzenhoff, D., Coghlan, M. J., Harris, R., and Krafte, D. S. (2002). Tenidap, a novel anti-inflammatory agent, is an opener of the inwardly rectifying K+ channel hKir2.3. Eur. J. Pharmacol. 435, 153-160. doi: 10.1016/S0014-2999(01)01590-4

Löscher, W., Klitgaard, H., Twyman, R. E., and Schmidt, D. (2013). New avenues for anti-epileptic drug discovery and development. Nat. Rev. Drug Discov. 12, 757-776. doi: $10.1038 / \mathrm{nrd} 4126$

Lothman, E. W., Stringer, J. L., and Bertram, E. H. (1992). The dentate gyrus as a control point for seizures in the hippocampus and beyond. Epilepsy Res. Suppl. 7, 301-313.

Loup, F., Wieser, H. G., Yonekawa, Y., Aguzzi, A., and Fritschy, J. M. (2000). Selective alterations in GABAA receptor subtypes in human temporal lobe epilepsy. J. Neurosci. 20, 5401-5419.

Lu, Q., Peevey, J., Jow, F., Monaghan, M. M., Mendoza, G., Zhang, H., et al. (2008). Disruption of Kv1.1 N-type inactivation by novel small molecule inhibitors (disinactivators). Bioorg. Med. Chem. 16, 3067-3075. doi: 10.1016/j.bmc.2007.12.031

Ludwig, A., Budde, T., Stieber, J., Moosmang, S., Wahl, C., Holthoff, K., et al. (2003). Absence epilepsy and sinus dysrhythmia in mice lacking the pacemaker channel HCN2. EMBO J. 22, 216-224. doi: 10.1093/emboj/cdg032

Lugo, J. N., Barnwell, L. F., Ren, Y., Lee, W. L., Johnston, L. D., Kim, R., et al. (2008). Altered phosphorylation and localization of the A-type channel, Kv4.2 in status epilepticus. J. Neurochem. 106, 1929-1940. doi: 10.1111/j.14714159.2008.05508.x

Lukasiuk, K., and Pitkanen, A. (2004). Large-scale analysis of gene expression in epilepsy research: is synthesis already possible? Neurochem. Res. 29, 1169-1178. doi: 10.1023/B:NERE.0000023604.91584.6c

Ma, W., Berg, J., and Yellen, G. (2007). Ketogenic diet metabolites reduce firing in central neurons by opening K(ATP) channels. J. Neurosci. 27, 3618-3625. doi: 10.1523/JNEUROSCI.0132-07.2007

Madeja, M., Margineanu, D. G., Gorji, A., Siep, E., Boerrigter, P., Klitgaard, H., et al. (2003). Reduction of voltage-operated potassium currents by levetiracetam: a novel antiepileptic mechanism of action? Neuropharmacology 45, 661-671. doi: 10.1016/S0028-3908(03)00248-X

Magee, J. C. (1999). Dendritic lh normalizes temporal summation in hippocampal CA1 neurons. Nat. Neurosci. 2, 508-514. doi: 10.1038/9158

Magloczky, Z., and Freund, T. F. (1995). Delayed cell death in the contralateral hippocampus following kainate injection into the CA3 subfield. Neuroscience 66, 847-860. doi: 10.1016/0306-4522(94)00613-A

Magloczky, Z., and Freund, T. F. (2005). Impaired and repaired inhibitory circuits in the epileptic human hippocampus. Trends Neurosci. 28, 334-340. doi: 10.1016/j.tins.2005.04.002
Magloczky, Z., Halasz, P., Vajda, J., Czirjak, S., and Freund, T. F. (1997). Loss of Calbindin-D28K immunoreactivity from dentate granule cells in human temporal lobe epilepsy. Neuroscience 76, 377-385. doi: 10.1016/S03064522(96)00440-X

Main, M. J., Cryan, J. E., Dupere, J. R., Cox, B., Clare, J. J., and Burbidge, S. A. (2000). Modulation of KCNQ2/3 potassium channels by the novel anticonvulsant retigabine. Mol. Pharmacol. 58, 253-262.

Marcelin, B., Chauviere, L., Becker, A., Migliore, M., Esclapez, M., and Bernard, C. (2009). h channel-dependent deficit of theta oscillation resonance and phase shift in temporal lobe epilepsy. Neurobiol. Dis. 33, 436-447. doi: 10.1016/j.nbd.2008.11.019

Marder, E., and Goaillard, J. M. (2006). Variability, compensation and homeostasis in neuron and network function. Nat. Rev. Neurosci. 7, 563-574. doi: $10.1038 / \mathrm{nrn} 1949$

Margerison, J. H., and Corsellis, J. A. (1966). Epilepsy and the temporal lobes. A clinical, electroencephalographic and neuropathological study of the brain in epilepsy, with particular reference to the temporal lobes. Brain 89, 499-530. doi: 10.1093/brain/89.3.499

Martin, M. S., Dutt, K., Papale, L. A., Dube, C. M., Dutton, S. B., De Haan, G., et al. (2010). Altered function of the SCN1A voltage-gated sodium channel leads to gamma-aminobutyric acid-ergic (GABAergic) interneuron abnormalities. J. Biol. Chem. 285, 9823-9834. doi: 10.1074/jbc.M109.078568

Mashimo, T., Ohmori, I., Ouchida, M., Ohno, Y., Tsurumi, T., Miki, T., et al. (2010). A missense mutation of the gene encoding voltage-dependent sodium channel (Nav1.1) confers susceptibility to febrile seizures in rats. J. Neurosci. 30, 5744-5753. doi: 10.1523/JNEUROSCI.3360-09.2010

Mathern, G. W., Adelson, P. D., Cahan, L. D., and Leite, J. P. (2002). Hippocampal neuron damage in human epilepsy: Meyer's hypothesis revisited. Prog. Brain Res. 135, 237-251. doi: 10.1016/s0079-6123(02)35023-4

Mattia, D., Nagao, T., Rogawski, M. A., and Avoli, M. (1994). Potassium channel activators counteract anoxic hyperexcitability but not 4-aminopyridineinduced epileptiform activity in the rat hippocampal slice. Neuropharmacology 33, 1515-1522. doi: 10.1016/0028-3908(94)90124-4

Mcclelland, S., Flynn, C., Dube, C., Richichi, C., Zha, Q., Ghestem, A., et al. (2011). Neuron-restrictive silencer factor-mediated hyperpolarization-activated cyclic nucleotide gated channelopathy in experimental temporal lobe epilepsy. Ann. Neurol. 70, 454-464. doi: 10.1002/ana.22479

Mcnamara, J. O. (1984). Kindling: an animal model of complex partial epilepsy. Ann. Neurol. 16(Suppl.), S72-S76. doi: 10.1002/ana.410160712

Mehranfard, N., Gholamipour-Badie, H., Motamedi, F., Janahmadi, M., and Naderi, N. (2014a). The effect of paxilline on early alterations of electrophysiological properties of dentate gyrus granule cells in pilocarpinetreated rats. Iran. J. Pharm. Res. 13, 125-132. doi: 10.9734/ARRB/2014/ 11778

Mehranfard, N., Gholamipour-Badie, H., Motamedi, F., Janahmadi, M., and Naderi, N. (2014b). Occurrence of two types of granule cells with different excitability in rat dentate gyrus granule cell layer following pilocarpineinduced status epilepticus. Annu. Res. Rev. Biol. 4, 3707-3715. doi: 10.9734/ARRB/2014/11778

Meier, J., Semtner, M., Winkelmann, A., and Wolfart, J. (2014). Presynaptic mechanisms of neuronal plasticity and their role in epilepsy. Front. Cell. Neurosci. 8:164. doi: 10.3389/fncel.2014.00164

Meier, J., Semtner, M., and Wolfart, J. (2015). "Homeostasis of neuronal excitability via synaptic and intrinsic inhibitory mechanisms," in Homeostatic Control of Brain Function, eds. D. Boison and S. A. Masino (Oxford: Oxford University Press).

Meldrum, B. S., and Rogawski, M. A. (2007). Molecular targets for antiepileptic drug development. Neurotherapeutics 4, 18-61. doi: 10.1016/j.nurt.2006.11.010

Menteyne, A., Levavasseur, F., Audinat, E., and Avignone, E. (2009). Predominant functional expression of Kv1.3 by activated microglia of the hippocampus after Status epilepticus. PLoS One 4:e6770. doi: 10.1371/journal.pone.0006770

Misonou, H., Menegola, M., Mohapatra, D. P., Guy, L. K., Park, K. S., and Trimmer, J. S. (2006). Bidirectional activity-dependent regulation of neuronal ion channel phosphorylation. J. Neurosci. 26, 13505-13514. doi: 10.1523/JNEUROSCI.3970-06.2006

Mody, I., Kohr, G., Otis, T. S., and Staley, K. J. (1992a). The electrophysiology of dentate gyrus granule cells in whole-cell recordings. Epilepsy Res. Suppl. 7, 159-168. 
Mody, I., Otis, T. S., Staley, K. J., and Kohr, G. (1992b). The balance between excitation and inhibition in dentate granule cells and its role in epilepsy. Epilepsy Res. Suppl. 9, 331-339.

Molnar, P., and Nadler, J. V. (1999). Mossy fiber-granule cell synapses in the normal and epileptic rat dentate gyrus studied with minimal laser photostimulation. J. Neurophysiol. 82, 1883-1894.

Monaghan, M. M., Menegola, M., Vacher, H., Rhodes, K. J., and Trimmer, J. S. (2008). Altered expression and localization of hippocampal A-type potassium channel subunits in the pilocarpine-induced model of temporal lobe epilepsy. Neuroscience 156, 550-562. doi: 10.1016/j.neuroscience.2008.07.057

Morgan, R. J., and Soltesz, I. (2008). Nonrandom connectivity of the epileptic dentate gyrus predicts a major role for neuronal hubs in seizures. Proc. Natl. Acad. Sci. U.S.A. 105, 6179-6184. doi: 10.1073/pnas.0801372105

Morimoto, K., Fahnestock, M., and Racine, R. J. (2004). Kindling and status epilepticus models of epilepsy: rewiring the brain. Prog. Neurobiol. 73, 1-60. doi: 10.1016/j.pneurobio.2004.03.009

Motti, D., Le Duigou, C., Eugene, E., Chemaly, N., Wittner, L., Lazarevic, D., et al. (2010). Gene expression analysis of the emergence of epileptiform activity after focal injection of kainic acid into mouse hippocampus. Eur. J. Neurosci. 32, 1364-1379. doi: 10.1111/j.1460-9568.2010.07403.x

Mucha, M., Ooi, L., Linley, J. E., Mordaka, P., Dalle, C., Robertson, B., et al. (2010). Transcriptional control of KCNQ channel genes and the regulation of neuronal excitability. J. Neurosci. 30, 13235-13245. doi: 10.1523/JNEUROSCI.198110.2010

Mueller, S. G., Laxer, K. D., Schuff, N., and Weiner, M. W. (2007). Voxel-based T2 relaxation rate measurements in temporal lobe epilepsy (TLE) with and without mesial temporal sclerosis. Epilepsia 48, 220-228. doi: 10.1111/j.15281167.2006.00916.x

Munoz, A., Arellano, J. I., and Defelipe, J. (2002). GABABR1 receptor protein expression in human mesial temporal cortex: changes in temporal lobe epilepsy. J. Comp. Neurol. 449, 166-179. doi: 10.1002/cne.10287

Nadler, J. V., Perry, B. W., and Cotman, C. W. (1978). Intraventricular kainic acid preferentially destroys hippocampal pyramidal cells. Nature 271, 676-677. doi: $10.1038 / 271676 \mathrm{a} 0$

Nagao, Y., Harada, Y., Mukai, T., Shimizu, S., Okuda, A., Fujimoto, M., et al. (2013). Expressional analysis of the astrocytic Kir4.1 channel in a pilocarpineinduced temporal lobe epilepsy model. Front. Cell. Neurosci. 7:104. doi: $10.3389 /$ fncel.2013.00104

Nassirpour, R., Bahima, L., Lalive, A. L., Lüscher, C., Lujan, R., and Slesinger, P. A. (2010). Morphine- and CaMKII-dependent enhancement of GIRK channel signaling in hippocampal neurons. J. Neurosci. 30, 13419-13430. doi: 10.1523/JNEUROSCI.2966-10.2010

Noam, Y., Bernard, C., and Baram, T. Z. (2011). Towards an integrated view of HCN channel role in epilepsy. Curr. Opin. Neurobiol. 21, 873-879. doi: 10.1016/ j.conb.2011.06.013

O’Malley, D., and Harvey, J. (2007). MAPK-dependent actin cytoskeletal reorganization underlies BK channel activation by insulin. Eur. J. Neurosci. 25, 673-682. doi: 10.1111/j.1460-9568.2007.05347.x

Ogiwara, I., Miyamoto, H., Morita, N., Atapour, N., Mazaki, E., Inoue, I., et al. (2007). Nav1.1 localizes to axons of parvalbumin-positive inhibitory interneurons: a circuit basis for epileptic seizures in mice carrying an Scnla gene mutation. J. Neurosci. 27, 5903-5914. doi: 10.1523/JNEUROSCI.527006.2007

Oh, Y. J., Na, J., Jeong, J. H., Park, D. K., Park, K. H., Ko, J. S., et al. (2012). Alterations in hyperpolarization-activated cyclic nucleotidegated cation channel (HCN) expression in the hippocampus following pilocarpine-induced status epilepticus. BMB Rep. 45, 635-640. doi: 10.5483/BMBRep.2012.45.11.091

Okamoto, O. K., Janjoppi, L., Bonone, F. M., Pansani, A. P., Da Silva, A. V., Scorza, F. A., et al. (2010). Whole transcriptome analysis of the hippocampus: toward a molecular portrait of epileptogenesis. BMC Genomics 11:230. doi: 10.1186/1471-2164-11-230

Okazaki, M. M., Molnar, P., and Nadler, J. V. (1999). Recurrent mossy fiber pathway in rat dentate gyrus: synaptic currents evoked in presence and absence of seizure-induced growth. J. Neurophysiol. 81, 1645-1660.

Oliveira, M. S., Skinner, F., Arshadmansab, M. F., Garcia, I., Mello, C. F., Knaus, H. G., et al. (2010). Altered expression and function of small-conductance (SK) $\mathrm{Ca}(2+)$-activated $\mathrm{K}+$ channels in pilocarpine-treated epileptic rats. Brain Res. 1348, 187-199. doi: 10.1016/j.brainres.2010.05.095
Olney, J. W., and Sharpe, L. G. (1969). Brain lesions in an infant rhesus monkey treated with monsodium glutamate. Science 166, 386-388. doi: 10.1126/science.166.3903.386

Otto, J. F., Kimball, M. M., and Wilcox, K. S. (2002). Effects of the anticonvulsant retigabine on cultured cortical neurons: changes in electroresponsive properties and synaptic transmission. Mol. Pharmacol. 61, 921-927. doi: 10.1124/mol.61.4.921

Otto, J. F., Yang, Y., Frankel, W. N., White, H. S., and Wilcox, K. S. (2006). A spontaneous mutation involving Kcnq2 (Kv7.2) reduces M-current density and spike frequency adaptation in mouse CA1 neurons. J. Neurosci. 26, 2053-2059. doi: 10.1523/JNEUROSCI.1575-05.2006

Pacheco Otalora, L. F., Hernandez, E. F., Arshadmansab, M. F., Francisco, S., Willis, M., Ermolinsky, B., et al. (2008). Down-regulation of BK channel expression in the pilocarpine model of temporal lobe epilepsy. Brain Res. 1200, 116-131. doi: 10.1016/j.brainres.2008.01.017

Palma, E., Amici, M., Sobrero, F., Spinelli, G., Di Angelantonio, S., Ragozzino, D., et al. (2006). Anomalous levels of $\mathrm{Cl}$ - transporters in the hippocampal subiculum from temporal lobe epilepsy patients make GABA excitatory. Proc. Natl. Acad. Sci. U.S.A. 103, 8465-8468. doi: 10.1073/pnas.0602979103

Pathak, H. R., Weissinger, F., Terunuma, M., Carlson, G. C., Hsu, F. C., Moss, S. J., et al. (2007). Disrupted dentate granule cell chloride regulation enhances synaptic excitability during development of temporal lobe epilepsy. J. Neurosci. 27, 14012-14022. doi: 10.1523/JNEUROSCI.4390-07.2007

Pei, Q., Burnet, P. W., Grahame-Smith, D. G., and Zetterstrom, T. S. (1997). Differential effects of acute and chronic electroconvulsive shock on the abundance of messenger RNAs for voltage-dependent potassium channel subunits in the rat brain. Neuroscience 78, 343-350. doi: 10.1016/S03064522(96)00574-X

Peng, B. W., Justice, J. A., Zhang, K., He, X. H., and Sanchez, R. M. (2010). Increased basal synaptic inhibition of hippocampal area CA1 pyramidal neurons by an antiepileptic drug that enhances $\mathrm{I}(\mathrm{H})$. Neuropsychopharmacology 35, 464-472. doi: 10.1038/npp.2009.150

Peng, Z., Hauer, B., Mihalek, R. M., Homanics, G. E., Sieghart, W., Olsen, R. W., et al. (2002). GABA(A) receptor changes in delta subunit-deficient mice: altered expression of alpha4 and gamma2 subunits in the forebrain. J. Comp. Neurol. 446, 179-197. doi: 10.1002/cne.10210

Peng, Z., Huang, C. S., Stell, B. M., Mody, I., and Houser, C. R. (2004). Altered expression of the delta subunit of the GABAA receptor in a mouse model of temporal lobe epilepsy. J. Neurosci. 24, 8629-8639. doi: 10.1523/JNEUROSCI.2877-04.2004

Penschuck, S., Bastlund, J. F., Jensen, H. S., Stensbol, T. B., Egebjerg, J., and Watson, W. P. (2005). Changes in KCNQ2 immunoreactivity in the amygdala in two rat models of temporal lobe epilepsy. Brain Res. Mol. Brain Res. 141, 66-73. doi: 10.1016/j.molbrainres.2005.08.004

Peters, H. C., Hu, H., Pongs, O., Storm, J. F., and Isbrandt, D. (2005). Conditional transgenic suppression of $\mathrm{M}$ channels in mouse brain reveals functions in neuronal excitability, resonance and behavior. Nat. Neurosci. 8, 51-60. doi: $10.1038 / \mathrm{nn} 1375$

Pongs, O. (1992). Structural basis of voltage-gated K+ channel pharmacology. Trends Pharmacol. Sci. 13, 359-365. doi: 10.1016/0165-6147(92)90109-J

Poolos, N. P. (2004). The Yin and Yang of the H-Channel and Its role in epilepsy. Epilepsy Curr. 4, 3-6. doi: 10.1111/j.1535-7597.2004.04101.x

Poolos, N. P. (2009). Genetic loss of HCN1 channels is exciting, but is it epileptic? Epilepsy Curr. 10, 51-52. doi: 10.1111/j.1535-7511.2009.01352.x

Poolos, N. P., and Johnston, D. (2012). Dendritic ion channelopathy in acquired epilepsy. Epilepsia 53 (Suppl. 9), 32-40. doi: 10.1111/epi.12033

Poolos, N. P., Migliore, M., and Johnston, D. (2002). Pharmacological upregulation of h-channels reduces the excitability of pyramidal neuron dendrites. Nat. Neurosci. 5, 767-774. doi: 10.1038/nn891

Pothmann, L., Muller, C., Averkin, R. G., Bellistri, E., Miklitz, C., Uebachs, M., et al. (2014). Function of inhibitory micronetworks is spared by $\mathrm{Na}+$ channel-acting anticonvulsant drugs. J. Neurosci. 34, 9720-9735. doi: 10.1523/JNEUROSCI.2395-13.2014

Powell, K. L., Lukasiuk, K., O’brien, T. J., and Pitkanen, A. (2014). Are alterations in transmitter receptor and ion channel expression responsible for epilepsies? Adv. Exp. Med. Biol. 813, 211-229. doi: 10.1007/978-94-017-8914-1_17

Powell, K. L., Ng, C., O’brien, T. J., Xu, S. H., Williams, D. A., Foote, S. J., et al. (2008). Decreases in HCN mRNA expression in the hippocampus after 
kindling and status epilepticus in adult rats. Epilepsia 49, 1686-1695. doi: 10.1111/j.1528-1167.2008.01593.x

Prakriya, M., and Mennerick, S. (2000). Selective depression of low-release probability excitatory synapses by sodium channel blockers. Neuron 26, 671-682. doi: 10.1016/S0896-6273(00)81203-9

Ptacek, L. J. (1997). Channelopathies: ion channel disorders of muscle as a paradigm for paroxysmal disorders of the nervous system. Neuromuscul. Disord. 7, 250-255. doi: 10.1016/S0960-8966(97)00046-1

Qiao, X., Werkman, T. R., Gorter, J. A., Wadman, W. J., and Van Vliet, E. A. (2013). Expression of sodium channel alpha subunits 1.1, 1.2 and 1.6 in rat hippocampus after kainic acid-induced epilepsy. Epilepsy Res. 106, 17-28. doi: 10.1016/j.eplepsyres.2013.06.006

Qiu, C., Zeyda, T., Johnson, B., Hochgeschwender, U., De Lecea, L., and Tallent, M. K. (2008). Somatostatin receptor subtype 4 couples to the M-current to regulate seizures. J. Neurosci. 28, 3567-3576. doi: 10.1523/JNEUROSCI.4679-07.2008

Raol, Y. H., Lapides, D. A., Keating, J. G., Brooks-Kayal, A. R., and Cooper, E. C. (2009). A KCNQ channel opener for experimental neonatal seizures and status epilepticus. Ann. Neurol. 65, 326-336. doi: 10.1002/ana.21593

Raol, Y. H., Lund, I. V., Bandyopadhyay, S., Zhang, G., Roberts, D. S., Wolfe, J. H., et al. (2006a). Enhancing GABA(A) receptor alpha 1 subunit levels in hippocampal dentate gyrus inhibits epilepsy development in an animal model of temporal lobe epilepsy. J. Neurosci. 26, 11342-11346. doi: 10.1523/ JNEUROSCI.3329-06.2006

Raol, Y. H., Zhang, G., Lund, I. V., Porter, B. E., Maronski, M. A., and BrooksKayal, A. R. (2006b). Increased GABA(A)-receptor alpha1-subunit expression in hippocampal dentate gyrus after early-life status epilepticus. Epilepsia 47, 1665-1673. doi: 10.1111/j.1528-1167.2006.00640.x

Raza, M., Blair, R. E., Sombati, S., Carter, D. S., Deshpande, L. S., and Delorenzo, R. J. (2004). Evidence that injury-induced changes in hippocampal neuronal calcium dynamics during epileptogenesis cause acquired epilepsy. Proc. Natl. Acad. Sci. U.S.A. 101, 17522-17527. doi: 10.1073/pnas.0408155101

Riazanski, V., Deriy, L. V., Shevchenko, P. D., Le, B., Gomez, E. A., and Nelson, D. J. (2011). Presynaptic CLC-3 determines quantal size of inhibitory transmission in the hippocampus. Nat. Neurosci. 14, 487-494. doi: 10.1038/nn.2775

Rinke, I., Artmann, J., and Stein, V. (2010). ClC-2 voltage-gated channels constitute part of the background conductance and assist chloride extrusion. J. Neurosci. 30, 4776-4786. doi: 10.1523/JNEUROSCI.6299-09.2010

Robbins, C. A., and Tempel, B. L. (2012). Kv1.1 and Kv1.2: similar channels, different seizure models. Epilepsia 53(Suppl. 1), 134-141. doi: 10.1111/j.15281167.2012.03484.x

Roeloffs, R., Wickenden, A. D., Crean, C., Werness, S., Mcnaughton-Smith, G., Stables, J., et al. (2008). In vivo profile of ICA-27243 [N-(6-chloro-pyridin-3yl)-3,4-difluoro-benzamide], a potent and selective KCNQ2/Q3 (Kv7.2/Kv7.3) activator in rodent anticonvulsant models. J. Pharmacol. Exp. Ther. 326, 818-828. doi: 10.1124/jpet.108.137794

Rogawski, M. A., and Löscher, W. (2004). The neurobiology of antiepileptic drugs. Nat. Rev. Neurosci. 5, 553-564. doi: 10.1038/nrn1430

Rossignol, E., Kruglikov, I., Van Den Maagdenberg, A. M., Rudy, B., and Fishell, G. (2013). CaV 2.1 ablation in cortical interneurons selectively impairs fastspiking basket cells and causes generalized seizures. Ann. Neurol. 74, 209-222. doi: $10.1002 /$ ana. 23913

Rostock, A., Tober, C., Rundfeldt, C., Bartsch, R., Engel, J., Polymeropoulos, E. E., et al. (1996). D-23129: a new anticonvulsant with a broad spectrum activity in animal models of epileptic seizures. Epilepsy Res. 23, 211-223. doi: 10.1016/0920-1211(95)00101-8

Rundfeldt, C., and Netzer, R. (2000). The novel anticonvulsant retigabine activates $\mathrm{M}$-currents in Chinese hamster ovary-cells tranfected with human KCNQ2/3 subunits. Neurosci. Lett. 282, 73-76. doi: 10.1016/S0304-3940(00)00866-1

Ruppersberg, J. P., Stocker, M., Pongs, O., Heinemann, S. H., Frank, R., and Koenen, M. (1991). Regulation of fast inactivation of cloned mammalian IK(A) channels by cysteine oxidation. Nature 352, 711-714. doi: 10.1038/352711a0

Rüschenschmidt, C., Chen, J., Becker, A., Riazanski, V., and Beck, H. (2006). Functional properties and oxidative modulation of A-type $\mathrm{K}$ currents in hippocampal granule cells of control and chronically epileptic rats. Eur. J. Neurosci. 23, 675-685. doi: 10.1111/j.1460-9568.2006.04608.x

Sanabria, E. R., Su, H., and Yaari, Y. (2001). Initiation of network bursts by Ca2+dependent intrinsic bursting in the rat pilocarpine model of temporal lobe epilepsy. J. Physiol. 532, 205-216. doi: 10.1111/j.1469-7793.2001.0205g.x
Santoro, B., Lee, J. Y., Englot, D. J., Gildersleeve, S., Piskorowski, R. A., Siegelbaum, S. A., et al. (2010). Increased seizure severity and seizure-related death in mice lacking HCN1 channels. Epilepsia 51, 1624-1627. doi: 10.1111/j.15281167.2010.02554.x

Scharfman, H. E. (2002). Epilepsy as an example of neural plasticity. Neuroscientist 8, 154-173. doi: 10.1177/107385840200800211

Scharfman, H. E., Goodman, J. H., and Sollas, A. L. (2000). Granule-like neurons at the hilar/CA3 border after status epilepticus and their synchrony with area CA3 pyramidal cells: functional implications of seizure-induced neurogenesis. J. Neurosci. 20, 6144-6158.

Scharfman, H. E., Sollas, A. L., Berger, R. E., and Goodman, J. H. (2003). Electrophysiological evidence of monosynaptic excitatory transmission between granule cells after seizure-induced mossy fiber sprouting. J. Neurophysiol. 90, 2536-2547. doi: 10.1152/jn.00251.2003

Schenzer, A., Friedrich, T., Pusch, M., Saftig, P., Jentsch, T. J., Grotzinger, J., et al. (2005). Molecular determinants of KCNQ (Kv7) K+ channel sensitivity to the anticonvulsant retigabine. J. Neurosci. 25, 5051-5060. doi: 10.1523/JNEUROSCI.0128-05.2005

Schroeder, B. C., Kubisch, C., Stein, V., and Jentsch, T. J. (1998). Moderate loss of function of cyclic-AMP-modulated KCNQ2/KCNQ3 $\mathrm{K}+$ channels causes epilepsy. Nature 396, 687-690. doi: 10.1038/25367

Schulte, U., Thumfart, J. O., Klocker, N., Sailer, C. A., Bildl, W., Biniossek, M., et al. (2006). The epilepsy-linked Lgil protein assembles into presynaptic Kv1 channels and inhibits inactivation by Kvbeta1. Neuron 49, 697-706. doi: 10.1016/j.neuron.2006.01.033

Schulz, R., Kirschstein, T., Brehme, H., Porath, K., Mikkat, U., and Köhling, R. (2012). Network excitability in a model of chronic temporal lobe epilepsy critically depends on SK channel-mediated AHP currents. Neurobiol. Dis. 45, 337-347. doi: 10.1016/j.nbd.2011.08.019

Schwob, J. E., Fuller, T., Price, J. L., and Olney, J. W. (1980). Widespread patterns of neuronal damage following systemic or intracerebral injections of kainic acid: a histological study. Neuroscience 5, 991-1014. doi: 10.1016/03064522(80)90181-5

Selke, K., Muller, A., Kukley, M., Schramm, J., and Dietrich, D. (2006). Firing pattern and calbindin-D28k content of human epileptic granule cells. Brain Res. 1120, 191-201. doi: 10.1016/j.brainres.2006.08.072

Shah, M. M., Anderson, A. E., Leung, V., Lin, X., and Johnston, D. (2004). Seizureinduced plasticity of $\mathrm{h}$ channels in entorhinal cortical layer III pyramidal neurons. Neuron 44, 495-508. doi: 10.1016/j.neuron.2004.10.011

Shah, M. M., Huang, Z., and Martinello, K. (2013). HCN and KV7 (M-) channels as targets for epilepsy treatment. Neuropharmacology 69, 75-81. doi: 10.1016/j.neuropharm.2012.03.005

Shin, M., Brager, D., Jaramillo, T. C., Johnston, D., and Chetkovich, D. M. (2008). Mislocalization of $\mathrm{h}$ channel subunits underlies $\mathrm{h}$ channelopathy in temporal lobe epilepsy. Neurobiol. Dis. 32, 26-36. doi: 10.1016/j.nbd.2008.06.013

Shruti, S., Clem, R. L., and Barth, A. L. (2008). A seizure-induced gain-offunction in BK channels is associated with elevated firing activity in neocortical pyramidal neurons. Neurobiol. Dis. 30, 323-330. doi: 10.1016/j.nbd.2008. 02.002

Sicca, F., Imbrici, P., D’adamo, M. C., Moro, F., Bonatti, F., Brovedani, P., et al. (2011). Autism with seizures and intellectual disability: possible causative role of gain-of-function of the inwardly-rectifying K+ channel Kir4.1. Neurobiol. Dis. 43, 239-247. doi: 10.1016/j.nbd.2011.03.016

Signorini, S., Liao, Y. J., Duncan, S. A., Jan, L. Y., and Stoffel, M. (1997). Normal cerebellar development but susceptibility to seizures in mice labievcking $\mathrm{G}$ protein-coupled, inwardly rectifying K+ channel GIRK2. Proc. Natl. Acad. Sci. U.S.A. 94, 923-927. doi: 10.1073/pnas.94.3.923

Sills, G. J. (2007). Seizures beget seizures: a lack of experimental evidence and clinical relevance fails to dampen enthusiasm. Epilepsy Curr. 7, 103-104. doi: 10.1111/j.1535-7511.2007.00189.x

Singh, N. A., Charlier, C., Stauffer, D., Dupont, B. R., Leach, R. J., Melis, R., et al. (1998). A novel potassium channel gene, KCNQ2, is mutated in an inherited epilepsy of newborns. Nat. Genet. 18, 25-29. doi: 10.1038/ng0198-25

Singh, N. A., Otto, J. F., Dahle, E. J., Pappas, C., Leslie, J. D., Vilaythong, A., et al. (2008). Mouse models of human KCNQ2 and KCNQ3 mutations for benign familial neonatal convulsions show seizures and neuronal plasticity without synaptic reorganization. J. Physiol. (Lond). 586, 3405-3423. doi: 10.1113/jphysiol.2008.154971 
Sloviter, R. S. (1987). Decreased hippocampal inhibition and a selective loss of interneurons in experimental epilepsy. Science 235, 73-76. doi: $10.1126 /$ science. 2879352

Sloviter, R. S. (1994). The functional organization of the hippocampal dentate gyrus and its relevance to the pathogenesis of temporal lobe epilepsy. Ann. Neurol. 35, 640-654. doi: 10.1002/ana.410350604

Smart, S. L., Lopantsev, V., Zhang, C. L., Robbins, C. A., Wang, H., Chiu, S. Y., et al. (1998). Deletion of the K(V)1.1 potassium channel causes epilepsy in mice. Neuron 20, 809-819. doi: 10.1016/S0896-6273(00)81018-1

Smith, S. E., Xu, L., Kasten, M. R., and Anderson, M. P. (2012). Mutant LGI1 inhibits seizure-induced trafficking of Kv4.2 potassium channels. J. Neurochem. 120, 611-621. doi: 10.1111/j.1471-4159.2011.07605.x

Sosanya, N. M., Brager, D. H., Wolfe, S., Niere, F., and Raab-Graham, K. F. (2014). Rapamycin reveals an mTOR-independent repression of Kv1.1 expression during epileptogenesis. Neurobiol. Dis. 73C, 96-105. doi: 10.1016/j.nbd.2014.09.011

Spencer, S. S. (2002). Neural networks in human epilepsy: evidence of and implications for treatment. Epilepsia 43, 219-227. doi: 10.1046/j.15281157.2002.26901.x

Spencer, S. S., and Spencer, D. D. (1994). Entorhinal-hippocampal interactions in medial temporal lobe epilepsy. Epilepsia 35, 721-727. doi: 10.1111/j.15281157.1994.tb02502.x

Spigelman, I., Li, Z., Banerjee, P. K., Mihalek, R. M., Homanics, G. E., and Olsen, R. W. (2002). Behavior and physiology of mice lacking the GABAA-receptor delta subunit. Epilepsia 43(Suppl. 5), 3-8. doi: 10.1046/j.1528-1157.43.s.5.8.x

Splinter, M. Y. (2013). Efficacy of retigabine in adjunctive treatment of partial onset seizures in adults. J. Cent. Nerv. Syst. Dis. 5, 31-41. doi: 10.4137/JCNSD.S9299

Stabel, J., Ficker, E., and Heinemann, U. (1992). Young CA1 pyramidal cells of rats, but not dentate gyrus granule cells, express a delayed inward rectifying current with properties of IQ. Neurosci. Lett. 135, 231-234. doi: 10.1016/03043940(92)90443-B

Staley, K. J., and Mody, I. (1992). Shunting of excitatory input to dentate gyrus granule cells by a depolarizing GABAA receptor-mediated postsynaptic conductance. J. Neurophysiol. 68, 197-212.

Stegen, M., Kirchheim, F., Hanuschkin, A., Staszewski, O., Veh, R. W., and Wolfart, J. (2012). Adaptive intrinsic plasticity in human dentate gyrus granule cells during temporal lobe epilepsy. Cereb. Cortex 22, 2087-2101. doi: 10.1093/cercor/bhr294

Stegen, M., Young, C. C., Haas, C. A., Zentner, J., and Wolfart, J. (2009). Increased leak conductance in dentate gyrus granule cells of temporal lobe epilepsy patients with Ammon's horn sclerosis. Epilepsia 50, 646-653. doi: 10.1111/j.1528-1167.2009.02025.x

Stogmann, E., Lichtner, P., Baumgartner, C., Schmied, M., Hotzy, C., Asmus, F., et al. (2006). Mutations in the CLCN2 gene are a rare cause of idiopathic generalized epilepsy syndromes. Neurogenetics 7, 265-268. doi: 10.1007/s10048-006-0057-x

Strauss, U., Kole, M. H., Brauer, A. U., Pahnke, J., Bajorat, R., Rolfs, A., et al. (2004). An impaired neocortical $\mathrm{Ih}$ is associated with enhanced excitability and absence epilepsy. Eur. J. Neurosci. 19, 3048-3058. doi: 10.1111/j.0953816X.2004.03392.x

Streit, A. K., Derst, C., Wegner, S., Heinemann, U., Zahn, R. K., and Decher, N. (2011). RNA editing of Kv1.1 channels may account for reduced ictogenic potential of 4-aminopyridine in chronic epileptic rats. Epilepsia 52, 645-648. doi: 10.1111/j.1528-1167.2011.02986.x

Su, H., Sochivko, D., Becker, A., Chen, J., Jiang, Y., Yaari, Y., et al. (2002). Upregulation of a T-type $\mathrm{Ca} 2+$ channel causes a long-lasting modification of neuronal firing mode after status epilepticus. J. Neurosci. 22, 3645-3655.

Su, T., Cong, W. D., Long, Y. S., Luo, A. H., Sun, W. W., Deng, W. Y., et al. (2008). Altered expression of voltage-gated potassium channel 4.2 and voltage-gated potassium channel 4 -interacting protein, and changes in intracellular calcium levels following lithium-pilocarpine-induced status epilepticus. Neuroscience 157, 566-576. doi: 10.1016/j.neuroscience.2008.09.027

Sun, C., Mtchedlishvili, Z., Erisir, A., and Kapur, J. (2007). Diminished neurosteroid sensitivity of synaptic inhibition and altered location of the alpha4 subunit of GABA(A) receptors in an animal model of epilepsy. J. Neurosci. 27, 12641-12650. doi: 10.1523/JNEUROSCI.4141-07.2007

Sun, Y., Wu, Z., Kong, S., Jiang, D., Pitre, A., Wang, Y., et al. (2013). Regulation of epileptiform activity by two distinct subtypes of extrasynaptic GABAA receptors. Mol. Brain 6:21. doi: 10.1186/1756-6606-6-21
Surges, R., Freiman, T. M., and Feuerstein, T. J. (2003). Gabapentin increases the hyperpolarization-activated cation current $\mathrm{Ih}$ in rat CA1 pyramidal cells. Epilepsia 44, 150-156. doi: 10.1046/j.1528-1157.2003.36802.x

Sutula, T., Cascino, G., Cavazos, J., Parada, I., and Ramirez, L. (1989). Mossy fiber synaptic reorganization in the epileptic human temporal lobe. Ann. Neurol. 26, 321-330. doi: 10.1002/ana.410260303

Sutula, T. P., Hagen, J., and Pitkanen, A. (2003). Do epileptic seizures damage the brain? Curr. Opin. Neurol. 16, 189-195. doi: 10.1097/01.wco.0000063770.15877.bc

Suzuki, F., Heinrich, C., Boehrer, A., Mitsuya, K., Kurokawa, K., Matsuda, M., et al. (2005). Glutamate receptor antagonists and benzodiazepine inhibit the progression of granule cell dispersion in a mouse model of mesial temporal lobe epilepsy. Epilepsia 46, 193-202. doi: 10.1111/j.0013-9580.2005.35504.x

Suzuki, F., Junier, M. P., Guilhem, D., Sorensen, J. C., and Onteniente, B. (1995). Morphogenetic effect of kainate on adult hippocampal neurons associated with a prolonged expression of brain-derived neurotrophic factor. Neuroscience 64, 665-674. doi: 10.1016/0306-4522(94)00463-F

Sypert, G. W., and Ward, A. A. Jr. (1967). The hyperexcitable neuron: microelectrode studies of the chronic epileptic focus in the intact, awake monkey. Exp. Neurol. 19, 104-114. doi: 10.1016/0014-4886(67)90010-6

Tatulian, L., Delmas, P., Abogadie, F. C., and Brown, D. A. (2001). Activation of expressed KCNQ potassium currents and native neuronal M-type potassium currents by the anti-convulsant drug retigabine. J. Neurosci. 21, 5535-5545.

Tauck, D. L., and Nadler, J. V. (1985). Evidence of functional mossy fiber sprouting in hippocampal formation of kainic acid-treated rats. J. Neurosci. 5, 1016-1022.

Taverna, S., Tkatch, T., Metz, A. E., and Martina, M. (2005). Differential expression of TASK channels between horizontal interneurons and pyramidal cells of rat hippocampus. J. Neurosci. 25, 9162-9170. doi: 10.1523/JNEUROSCI.245405.2005

Tellez-Zenteno, J. F., and Hernandez-Ronquillo, L. (2012). A review of the epidemiology of temporal lobe epilepsy. Epilepsy Res. Treat. 2012:630853. doi: $10.1155 / 2012 / 630853$

Thom, M., Mathern, G. W., Cross, J. H., and Bertram, E. H. (2010). Mesial temporal lobe epilepsy: How do we improve surgical outcome? Ann. Neurol. 68, 424-434. doi: 10.1002/ana.22142

Thom, M., Sisodiya, S. M., Beckett, A., Martinian, L., Lin, W. R., Harkness, W., et al. (2002). Cytoarchitectural abnormalities in hippocampal sclerosis. J. Neuropathol. Exp. Neurol. 61, 510-519.

Tomlinson, S. E., Tan, S. V., Kullmann, D. M., Griggs, R. C., Burke, D., Hanna, M. G., et al. (2010). Nerve excitability studies characterize Kv1.1 fast potassium channel dysfunction in patients with episodic ataxia type 1. Brain 133, 3530-3540. doi: 10.1093/brain/awq318

Tsaur, M. L., Sheng, M., Lowenstein, D. H., Jan, Y. N., and Jan, L. Y. (1992). Differential expression of $\mathrm{K}+$ channel mRNAs in the rat brain and downregulation in the hippocampus following seizures. Neuron 8, 1055-1067. doi: 10.1016/0896-6273(92)90127-Y

Turrigiano, G., Lemasson, G., and Marder, E. (1995). Selective regulation of current densities underlies spontaneous changes in the activity of cultured neurons. J. Neurosci. 15, 3640-3652.

Turrigiano, G. G., and Nelson, S. B. (2004). Homeostatic plasticity in the developing nervous system. Nat. Rev. Neurosci. 5, 97-107. doi: 10.1038/nrn1327

Turski, L., Ikonomidou, C., Turski, W. A., Bortolotto, Z. A., and Cavalheiro, E. A. (1989). Review: cholinergic mechanisms and epileptogenesis. The seizures induced by pilocarpine: a novel experimental model of intractable epilepsy. Synapse 3, 154-171. doi: 10.1002/syn.890030207

Turski, W. A., Cavalheiro, E. A., Schwarz, M., Czuczwar, S. J., Kleinrok, Z., and Turski, L. (1983). Limbic seizures produced by pilocarpine in rats: behavioural, electroencephalographic and neuropathological study. Behav. Brain Res. 9, 315-335. doi: 10.1016/0166-4328(83)90136-5

Van Welie, I., Van Hooft, J. A., and Wadman, W. J. (2004). Homeostatic scaling of neuronal excitability by synaptic modulation of somatic hyperpolarizationactivated Ih channels. Proc. Natl. Acad. Sci. U.S.A. 101, 5123-5128. doi: 10.1073/pnas.0307711101

Van Welie, I., Van Hooft, J. A., and Wadman, W. J. (2006). Background activity regulates excitability of rat hippocampal CA1 pyramidal neurons by adaptation of a $\mathrm{K}+$ conductance. J. Neurophysiol. 95, 2007-2012. doi: 10.1152/jn.00220.2005

Varga, A. W., Yuan, L. L., Anderson, A. E., Schrader, L. A., Wu, G. Y., Gatchel, J. R., et al. (2004). Calcium-calmodulin-dependent kinase II modulates Kv4.2 
channel expression and upregulates neuronal A-type potassium currents. J. Neurosci. 24, 3643-3654. doi: 10.1523/JNEUROSCI.0154-04.2004

Vida, I. (2009). 'Leaky' neurons in the epileptic hippocampus: should we get excited? J. Physiol. 587, 4127-4128. doi: 10.1113/jphysiol.2009

Vida, I., Bartos, M., and Jonas, P. (2006). Shunting inhibition improves robustness of gamma oscillations in hippocampal interneuron networks by homogenizing firing rates. Neuron 49, 107-117. doi: 10.1016/j.neuron.2005.11.036

Walleigh, D. J., Legido, A., and Valencia, I. (2013). Ring chromosome 20: a pediatric potassium channelopathy responsive to treatment with ezogabine. Pediatr. Neurol. 49, 368-369. doi: 10.1016/j.pediatrneurol.2013.06.005

Waxman, S. G. (2001). Transcriptional channelopathies: an emerging class of disorders. Nat. Rev. Neurosci. 2, 652-659. doi: 10.1038/35090026

Weckhuysen, S., Ivanovic, V., Hendrickx, R., Van Coster, R., Hjalgrim, H., Moller, R. S., et al. (2013). Extending the KCNQ2 encephalopathy spectrum: clinical and neuroimaging findings in 17 patients. Neurology 81, 1697-1703. doi: 10.1212/01.wnl.0000435296.72400.a1

Wei, A. D., Gutman, G. A., Aldrich, R., Chandy, K. G., Grissmer, S., and Wulff, H. (2005). International Union of Pharmacology. LII. Nomenclature and molecular relationships of calcium-activated potassium channels. Pharmacol. Rev. 57, 463-472. doi: 10.1124/pr.57.4.9

Wellmer, J., Su, H., Beck, H., and Yaari, Y. (2002). Long-lasting modification of intrinsic discharge properties in subicular neurons following status epilepticus. Eur. J. Neurosci. 16, 259-266. doi: 10.1046/j.1460-9568.2002.02086.x

Wenzel, H. J., Vacher, H., Clark, E., Trimmer, J. S., Lee, A. L., Sapolsky, R. M., et al. (2007). Structural consequences of Kcnal gene deletion and transfer in the mouse hippocampus. Epilepsia 48, 2023-2046. doi: 10.1111/j.15281167.2007.01189.x

Westenbroek, R. E., Bausch, S. B., Lin, R. C., Franck, J. E., Noebels, J. L., and Catterall, W. A. (1998). Upregulation of L-type Ca2+ channels in reactive astrocytes after brain injury, hypomyelination, and ischemia. J. Neurosci. 18, 2321-2334.

Whitaker, W. R., Faull, R. L., Dragunow, M., Mee, E. W., Emson, P. C., and Clare, J. J. (2001). Changes in the mRNAs encoding voltage-gated sodium channel types II and III in human epileptic hippocampus. Neuroscience 106, 275-285. doi: 10.1016/S0306-4522(01)00212-3

Wickenden, A. D. (2002). Potassium channels as anti-epileptic drug targets. Neuropharmacology 43, 1055-1060. doi: 10.1016/S0028-3908(02)00237-X

Wickenden, A. D., Krajewski, J. L., London, B., Wagoner, P. K., Wilson, W. A., Clark, S., et al. (2008). N-(6-chloro-pyridin-3-yl)-3,4-difluoro-benzamide (ICA-27243): a novel, selective KCNQ2/Q3 potassium channel activator. Mol. Pharmacol. 73, 977-986. doi: 10.1124/mol.107.043216

Wickenden, A. D., Yu, W., Zou, A., Jegla, T., and Wagoner, P. K. (2000). Retigabine, a novel anti-convulsant, enhances activation of KCNQ2/Q3 potassium channels. Mol. Pharmacol. 58, 591-600.

Wierschke, S., Lehmann, T. N., Dehnicke, C., Horn, P., Nitsch, R., and Deisz, R. A. (2010). Hyperpolarization-activated cation currents in human epileptogenic neocortex. Epilepsia 51, 404-414. doi: 10.1111/j.1528-1167.2009.02275.x

Wimmer, V. C., Reid, C. A., So, E. Y., Berkovic, S. F., and Petrou, S. (2010). Axon initial segment dysfunction in epilepsy. J. Physiol. 588, 1829-1840. doi: 10.1113/jphysiol.2010.188417

Wolfart, J., Debay, D., Le Masson, G., Destexhe, A., and Bal, T. (2005). Synaptic background activity controls spike transfer from thalamus to cortex. Nat. Neurosci. 8, 1760-1767. doi: 10.1038/nn1591

Wolfart, J., and Roeper, J. (2002). Selective coupling of T-type calcium channels to SK potassium channels prevents intrinsic bursting in dopaminergic midbrain neurons. J. Neurosci. 22, 3404-3413.

Wykes, R. C., Heeroma, J. H., Mantoan, L., Zheng, K., Macdonald, D. C., Deisseroth, K., et al. (2012). Optogenetic and potassium channel gene therapy in a rodent model of focal neocortical epilepsy. Sci. Transl. Med. 4, 161-152. doi: $10.1126 /$ scitranslmed. 3004190

Wyler, A. R., Dohan, F. C., Schweitzer, J. B., and Berry, A. D. (1992). A grading system for hippocampal sclerosis. J. Epilepsy 5, 220-225. doi: 10.1016/S08966974(05)80120-3

Xu, J. H., Long, L., Tang, Y. C., Hu, H. T., and Tang, F. R. (2007). Ca(v)1.2, Ca(v)1.3, and $\mathrm{Ca}(\mathrm{v}) 2.1$ in the mouse hippocampus during and after pilocarpine-induced status epilepticus. Hippocampus 17, 235-251. doi: 10.1002/hipo.20263
Xu, L., Hao, Y., Wu, X., Yu, P., Zhu, G., and Hong, Z. (2013a). Tenidap, an agonist of the inwardly rectifying $\mathrm{K}+$ channel Kir2.3, delays the onset of cortical epileptiform activity in a model of chronic temporal lobe epilepsy. Neurol. Res. 35, 561-567. doi: 10.1179/1743132813Y.0000000157

Xu, X., Guo, F., Lv, X., Feng, R., Min, D., Ma, L., et al. (2013b). Abnormal changes in voltage-gated sodium channels $\mathrm{Na}(\mathrm{V}) 1.1, \mathrm{Na}(\mathrm{V}) 1.2, \mathrm{Na}(\mathrm{V}) 1.3, \mathrm{Na}(\mathrm{V}) 1.6$ and in calmodulin/calmodulin-dependent protein kinase II, within the brains of spontaneously epileptic rats and tremor rats. Brain Res. Bull. 96, 1-9. doi: 10.1016/j.brainresbull.2013.04.003

Yaari, Y., and Beck, H. (2002). "Epileptic neurons" in temporal lobe epilepsy. Brain Pathol. 12, 234-239. doi: 10.1111/j.1750-3639.2002.tb00438.x

Yamada, K., Ji, J. J., Yuan, H., Miki, T., Sato, S., Horimoto, N., et al. (2001). Protective role of ATP-sensitive potassium channels in hypoxia-induced generalized seizure. Science 292, 1543-1546. doi: 10.1126/science.1059829

Yim, M. Y., Hanuschkin, A., and Wolfart, J. (2015). Intrinsic rescaling of granule cells restores pattern separation ability of a dentate gyrus network model during epileptic hyperexcitability. Hippocampus 25, 297-308. doi: 10.1002/hipo.22373

Young, C. C., Stegen, M., Bernard, R., Muller, M., Bischofberger, J., Veh, R. W., et al. (2009). Upregulation of inward rectifier $\mathrm{K}+(\mathrm{Kir} 2)$ channels in dentate gyrus granule cells in temporal lobe epilepsy. J. Physiol. 587, 4213-4233. doi: 10.1113/jphysiol.2009.170746

Yu, J., Proddutur, A., Elgammal, F. S., Ito, T., and Santhakumar, V. (2013). Status epilepticus enhances tonic GABA currents and depolarizes GABA reversal potential in dentate fast-spiking basket cells. J. Neurophysiol. 109, 1746-1763. doi: $10.1152 /$ jn. 00891.2012

Yus-Najera, E., Munoz, A., Salvador, N., Jensen, B. S., Rasmussen, H. B., Defelipe, J., et al. (2003). Localization of KCNQ5 in the normal and epileptic human temporal neocortex and hippocampal formation. Neuroscience 120, 353-364. doi: 10.1016/S0306-4522(03)00321-X

Zha, Q., Brewster, A. L., Richichi, C., Bender, R. A., and Baram, T. Z. (2008). Activity-dependent heteromerization of the hyperpolarization-activated, cyclic-nucleotide gated $(\mathrm{HCN})$ channels: role of N-linked glycosylation. J. Neurochem. 105, 68-77. doi: 10.1111/j.1471-4159.2007.05110.x

Zhang, G., Raol, Y. H., Hsu, F. C., Coulter, D. A., and BrooksKayal, A. R. (2004). Effects of status epilepticus on hippocampal GABAA receptors are age-dependent. Neuroscience 125, 299-303. doi: 10.1016/j.neuroscience.2004.01.040

Zhang, K., Peng, B. W., and Sanchez, R. M. (2006). Decreased IH in hippocampal area $\mathrm{CA1}$ pyramidal neurons after perinatal seizure-inducing hypoxia. Epilepsia 47, 1023-1028. doi: 10.1111/j.1528-1167.2006.00574.x

Zhang, N., Wei, W., Mody, I., and Houser, C. R. (2007). Altered localization of GABA(A) receptor subunits on dentate granule cell dendrites influences tonic and phasic inhibition in a mouse model of epilepsy. J. Neurosci. 27, 7520-7531. doi: 10.1523/JNEUROSCI.1555-07.2007

Zhou, P., Yu, H., Gu, M., Nan, F. J., Gao, Z., and Li, M. (2013). Phosphatidylinositol 4,5-bisphosphate alters pharmacological selectivity for epilepsy-causing KCNQ potassium channels. Proc. Natl. Acad. Sci. U.S.A. 110, 8726-8731. doi: $10.1073 /$ pnas. 1302167110

Ziemann, A. E., Schnizler, M. K., Albert, G. W., Severson, M. A., Howard, M. A. 3rd, Welsh, M. J., et al. (2008). Seizure termination by acidosis depends on ASIC1a. Nat. Neurosci. 11, 816-822. doi: 10.1038/nn.2132

Zuberi, S. M., Eunson, L. H., Spauschus, A., De Silva, R., Tolmie, J., Wood, N. W., et al. (1999). A novel mutation in the human voltage-gated potassium channel gene (Kv1.1) associates with episodic ataxia type 1 and sometimes with partial epilepsy. Brain 122(Pt 5), 817-825.

Conflict of Interest Statement: The authors declare that the research was conducted in the absence of any commercial or financial relationships that could be construed as a potential conflict of interest.

Copyright $\odot 2015$ Wolfart and Laker. This is an open-access article distributed under the terms of the Creative Commons Attribution License (CC BY). The use, distribution or reproduction in other forums is permitted, provided the original author(s) or licensor are credited and that the original publication in this journal is cited, in accordance with accepted academic practice. No use, distribution or reproduction is permitted which does not comply with these terms. 